\title{
BOŞANMANIN MALİ SONUÇLARI.
}

\section{1-GİRIŞ.}

Dr. Ömer ARBEK

Aile, toplumun temelidir. Nitekim, bu değer yargıs1, bütün dünyada kabul görmüş ve en temel hukuk normlarından birisi olan İnsan Hakları Evrensel Beyannamesi'nin ${ }^{1}$ 16. maddesinin üçüncü fikrasında, 'Aile, cemiyetin tabii ve temel unsurudur; cemiyet ve devlet tarafından korunmak hakkını haizdir"' şeklinde ifadesini bulmuştur. Keza, aynı fikir, Avrupa İnsan Hakları Sözleşmesi'nin ${ }^{2}$ 12. maddesinde "Evlenme çağına gelen erkek ve kadın, bu hakkın istimalini tanzim eden mili kanunlar dairesinde,evlenmek ve bir aile kurmak hakkına maliktir" şeklinde ifade edilmiştir.

Benzer düşünce, 1982 Tarihli Türkiye Cumhuriyeti Anayasası'nın³ 41. maddesinin birinci fikrasında ise, "Aile Türk toplumunun temelidir ve eşler arasında eşitliğe dayanır'' ş̧eklinde ifade edilmiştir.

Ayrıca, kanun koyucu, Medeni Kanun'un İkinci Kitabı'nda, 118. ve 494. maddeleri arasında, aile hukukunu ayrıntılı olarak düzenleyerek, bu konuya vermiş olduğu önemi bir kez daha ortaya koymuştur. Keza, yürürlükteki mevzuatta ${ }^{4}$, aileye hukukuna ilişkin olarak, çok sayıda başka düzenlemeler de yer almaktadır.

\footnotetext{
* Ankara Üniversitesi Hukuk Fakültesi Medeni Hukuk Anabilim Dalı Araştırma Görevlisi ${ }^{1}$ 06.05.1949 tarihinde kabul edilmiş ve 27.5.1949 Tarihli Resmi Gazete'de yayınlanmıştır.

2 10.3.1954 Kabul Tarihli ve 6366 Sayılı Avrupa İnsan Hakları Sözleşmesi, 19.3.1954 Tarihli ve 8662 Sayılı Resmi Gazetede yayınlanmıştır.

${ }^{3}$ 18.10.1982 Tarihli ve 2709 Sayılı Türkiye Cumhuriyeti Anayasası, 9.1.1982 Tarihli ve 17863 Sayılı Resmi Gazete'nin Mükerrer Sayısı'nda yayınlanmıştır.

${ }^{4}$ Aile hukukuna ilişkin olarak mevzuatta çok sayıda, milletlerarası anlaşmalar, özel kanunlar, tüzükler ve yönetmelikler mevcuttur. Bunlara örnek olara, 20.06.1995 Tarihli Nafaka Alacaklarının Yabancı Memleketlerde Tahsili ile İlgili New York Sözleşmesi; 24.10.1956 Tarihli Çocuklara Karşı Nafaka Mükellefiyetine Uygulanacak Kanuna Dair La Haye Sözleşmesi; 2.10.1973 Tarihli Nafaka Yükümlülüğüne Uygulanacak Kanuna Dair Sözleşme; 4320 Sayılı Ailenin Korunması Dair Kanun; 21.7.2002 Tarihli ve 2003/5960 Sayılı Türk Medeni Kanunu'nun Velayet Vesayet ve Miras Hükümlerinin Uygulanmasına Dair Tüzük; 28.7.2003 Tarihli ve 2003/5996 Sayılı Evlendirme Yönetmeliğinde Değişiklik Yapan Yönetmelik sayılabilir.
} 
Aile kavramının, hukuksal yönünün yanında, sosyal, ekonomik ve ahlaksal yönleri de vardır ${ }^{5}$. Zira, aile, millet olma şuurunun oluşmasında en önemli ve en etkin unsurlardan biridir ${ }^{6}$. Aile kavramı da, zaman içerisinde, toplumsal hayatta ortaya çıkan, hukuksal, siyasal, ekonomik, bilimsel ve teknolojik gelişmelere paralel olarak, yapısal bazı değişikliklere uğramış ve halen de uğramaktadır. Bu değişiklikler, esas itibariyle, sosyoloji ve antropoloji biliminin konusunu oluşturmakla beraber, kanun koyucunun kanun yaparken, bilimin yapmış olduğu tespitleri dikkate almaması düşünülemez.

Kanun koyucu tarafindan toplumun temeli olarak kabul edilen aile, kural olarak, hukuksal bir işlem olan evlenme sözleșmesiyle kurulmaktadır (MK. md. $125 \mathrm{vd}$.). Evlenme sözleşmesinin kurulmasıyla eşler, evlenmeden önceki hukuksal statülerinden farklı yeni bir hukuksal statüye kavuşmaktadırlar. Bu yeni hukuksal statü, eşlere yeni bazı haklar tanırken, aynı zamanda, bir takım yeni yükümlülükleri de beraberinde getirmektedir. Günlük yaşamda ve hukuk düzeninde arzu edilen asıl amaç, yapılan her evliliğin eşlerin hayatları boyunca devam etmesidir ${ }^{7}$. Ancak, yapılan evliliklerin bazılarının, çeşitli sebepten dolayı, hayat boyu devam etmediği de, hayatın bir gerçeğidir. Nitekim, bu gerçeklilikten hareket eden kanun koyucu, evlilik sözleşmesinin eşlere yüklediği yükümlülüklerin her zaman eşler tarafindan yerine getirilmesini aramamış ve dolayısıyla da gerekli olan boşanma müessesini Türk Medeni Kanunu'nda kabul ederek, bu konuyu, ayrıntılı bir biçimde de düzenlemiştir (MK. md.161 vd.).

Evlenme sonucunda nasıl eşlerin, ekonomik, sosyal, kişisel ve hukuksal statülerinde önemli bazı değişiklikler ve yenilikler meydana geliyorsa, boşanma sonucunda da, aynı şekilde boşanan eşlerin, sosyal, ekonomik, kişisel ve hukuksal statülerinde önemli bazı değişiklikler ve yenilikler meydana gelir ${ }^{9}$. Bu değişikler ve yenilikler, sadece boşanan eşler açısından

${ }^{5}$ Egger, August, Zürcher Kommentar, Familienrecht, 1. Abteilung, Das Eherecht (Art. 90251), 2. Aufl. Zürich 1936, (Çeviren, Çağa, Tahir, İstanbul 1943), sh. 5 vd.; Öztan, Bilge, Aile Hukuku, 5. Bası, Ankara 2004, sh. 4; Akıntürk, Turgut, Türk Medeni Hukuku, Yeni Medeni Kanuna Uyarlanmış Aile Hukuku, İkinci Cilt, 8. Bası, İstanbul, 2003. sh. 5; Köprülü; Bülent/Kaneti, Selim, Aile Hukuku, 2. Bası, İstanbul 1989, sh. 4.

${ }^{6}$ Feyzioğlu, Feyzi Necmeddin, Aile Hukuku Dersleri, İstanbul 1971, sh. 1. Palamut, Mehmet, E., Medeni Hukuk, İstanbul 2004, sh. 83; Birsen, Kemaleddin, Medeni Hukuk Dersleri, İstanbul 1954, sh. 212.

${ }^{7}$ Aile hukukunda geçerli olan ilkelerden birisi de ailenin devamlılığ ve birliği ilkesidir. Bu birlikteliğin hukuksal yönü kadar sosyal ve ahlaksal temelleri de vardır. Geniş bilgi için bkz., Öztan, sh. 15 vd.; Akıntürk, sh. 9 vd.; Köprülü/Kanati, sh. 5 vd.

${ }^{8}$ Boşanma hukukunun tarihsel gelişimi hakkında geniș bilgi için bkz., Gürsoy, Tahir Kemal, Boşanma Hukukunun Tarihi Gelişimine Genel Bir Bakış ve Boşanma Sebeplerinde En Yeni Eğilimler, Ankara Hukuk Fakültesi Ellinci Yıl Armağanı C. II, Boşanma Hukuku Haftası, Ankara 1977, sh. 1 vd.

9 Bühler, Walter/Spühler, Karl, Berner Kommentar, Kommentar zum Schweizerischen Privatrecht, Band II, Familienrecht, 1. Abteilung, Das Eherecht, Bern, 1979, Art. 151, N. 4. 
değil, aynı zamanda, ailenin diğer bireyleri açısından da söz konusudur. Ancak, ailenin diğer bireyleri, yani çocuklar bakımından ortaya çıkan bu değișiklikler ve yenilikler, bizim inceleme konumuz dișında olduğundan dolayı, çalışmamızda bu konulara incelenmeyecektir

Boşanmanın mali sonuçları, daha üst bir kavram olan boşanmanın hukuksal sonuçlarının ${ }^{10}$ en önemli kısmını oluşturur. Ancak, biz bu çalışmamızda, boşanmanın tüm hukuksal sonuçlarını değil, sadece boşanmanın fer'i sonuçlarından olan, boşanmanın boşanan taraflar açısından ortaya çıkardığı mali sonuçları ele alacağız.

$\mathrm{Bu}$ konuyu seçmekteki asıl amacımız, boşanmanın boşanan tarafların ekonomik hayatlarında meydana getirdiği etkidir. Zira, boşanmayla ortak yaşamlarına son veren taraflar, bundan sonra kendilerine yeni bir hayat kuracaklar ve bu hayatı kurarken de doğal olarak bazı ekonomik ihtiyaçlarla karşı karşıya kalacaklardır. Kural olarak, evlenme sözleşmesiyle yaşamların birleştiren eşler, aynı zamanda, ekonomik güçlerini de birleştirirlerdir. Ancak, boşanmayla boşanan taraflar, sadece ortak yaşamlarını değil, aynı zamanda, evlenmeyle birleştirdikleri ekonomik güçlerini de sona erdirerek, yeniden düzenlemek zorunda kalırlar.

Keza, boşanmaya kusuruyla sebep olan tarafın, karşı tarafın mevcut yada beklenen menfaatlerine veya kişilik hakkına genellikle zarar vermesi de muhtemeldir. Dolayısıyla, ortaya çıkan bu zararların hukuk düzeninde bir şekilde giderilmesi veya diğer bir ifadeyle, tazmin edilmesi de, doğal olarak, boşanma hukukunun ön önemli konularından birisini oluşturmaktadır.

Ayrıca, eşler, evlenme sonucunda, kanundan dolayı, her hangi bir hukuksal işleme gerek kalmaksızın birbirlerinin yasal mirasçıları olurlar. Keza, eşlerin evlilik birliğinin oluşturduğu bir takım duygu ve düşüncelerin etkisiyle, birbirleri lehine ölüme bağlı tasarrufta bulunmaları da her zaman muhtemeldir. Ancak, boşanan taraflar, boşanma kararının kesinleşmesi neticesinde, kural olarak, her hangi bir hukuksal işleme gerek kalmadan, hem birbirlerine olan yasal mirasçılık haklarını hem de ölüme bağlı tasarruftan eğer aksi anlaşılmıyorsa, ölüme bağlı tasarrufla sağlanan haklarını kaybederler.

Keza, Yeni Medeni Kanun'da boşanmanın mali sonuçlarına ilişkin olarak yapılan yeni ve önemli düzenlemeler de, bu konuyu seçmemizde etkin olmuş başka bir sebeptir.

Ancak, biz, bu çalışmamızda, boşanmanın mal rejimlerine olan etkisini ele almayacağız. Zira, boşanmanın mal rejimlere yaptığı etki, esas itibariyle, hem geniş hem de karmaşık bir konudur. $\mathrm{Bu}$ konular, çalışmamızın kapsamını aşar mahiyetedir ve dolayısıyla da mal rejimleri, ayrı ve müstakil bir çalışma konusunu olarak ele alınmalıdır.

Çalışma konumuzda, bir giriş, üç bölüm ve bir de sonuç yer almaktadır.

${ }^{10} \mathrm{Bu}$ kavram hakkında geniş bilgi için bkz., Akıntürk, Turgut, Boşanmanın Hukuki Sonuçları, Ankara Hukuk Fakültesi Ellinci Yıl Armağanı, sh. 175 vd. 


\section{BİRINCİ BÖLÜM. BOŞANMADA TAZMINAT.}

\section{2-GENEL OLARAK.}

Kanun koyucu, MK. md. 174'de, boşanma sonucunda maddi ve manevi zarara uğrayan tarafın, belirli koşullar altında, karşı taraftan tazminat talep edebileceğini hükme bağlamıştır. Kanun koyucunun Medeni Kanun'daki bu yaklaşımı, Medeni Kanun'un mehazını teşkil eden İsviçre Medeni Kanunu'ndan farkl111k arz etmektedir ${ }^{11}$. Türk kanun koyucusunun boşanmada maddi ve manevi zararların tazmin edilmesini Medeni Kanun'da ayrıca özel olarak düzenlemesi, her halde bu konuya verdiği önemden yada evlilik birliğinin boşanmayla sona ermesinin özel bir durum oluşturduğunu ve dolayısıyla da bu özel durumun bazı özel düzenlemelere ihtiyaç duyabileceğini düşünmesinden kaynaklanmaktadır.

Bizim de, katıldığımız görüşe göre, kanun koyucunun bu yöndeki tercihi, esas itibariyle, bir hukuk politikası sorunu olmakla beraber, pek de yerinde bir tercih olarak değerlendirilemez ${ }^{12}$. Nitekim, İsviçre'de de kanun koyucu, önceden İsviçre Medeni Kanunu'nda boşanmada maddi ve manevi tazminat1 özel olarak düzenlenmiştir ${ }^{13}$. Ancak, bu düzenlemeler, daha sonra kanunda yapılan bir değişikle tamamen ortadan kaldırılmış ve boşanmada maddi ve manevi tazminat, Borçlar Kanunu'ndaki genel hükümlere göre çözümlenmeye başlanmıştır ${ }^{14}$.

\section{3-BOSANMADA MADDİ TAZMINAT.}

\section{I-Genel Olarak.}

MK. md. 174/I göre, "mevcut veya beklenen menfaatleri boşanma yüzünden zedelenen kusursuz veya az kusurlu taraf, kusurlu taraftan uygun bir tazminat isteyebilir''. Kanun maddesinin metninden de kolayca anlaşıldığ gibi, kanun koyucu, boşanma halinde ortaya çıkan maddi zararın tazmin edilmesinde, genel hüküm olan BK. md. 41 vd. hükümlerinden farklı

\footnotetext{
${ }^{11}$ İsviçre kanun koyucusu, İsviçre Medeni Kanunu'nun (ZGB.) Aile Hukuku Kitabı'nda yer alan boşanmada maddi ve manevi tazminata ilişkin hükümleri, daha sonra yapmış olduğu bir değişiklikle tamamen ortadan kaldırmış İsviçre'de boşanmada maddi ve manevi tazminat sorunları artık Borçlar Kanunu'ndaki (OR.) genel hükümlere göre çözümlenmektedir.

12 Kılıçoğlu da, Medeni Kanun'daki maddi ve manevi tazminata ilişkin düzenlemenin İsviçre'deki çözümün örnek alınarak, Medeni Kanun'dan çıkartılması gerektiğini ve dolayısıyla da boşanma sonucunda ortaya çıkan tazminat sorununun Borçlar Kanunu'ndaki genel hükümlere göre çözülmesi gerektiği savunmaktadır. Geniş bilgi için bkz., Kılıçoğlu, sh. 16.

${ }^{13}$ İsviçre Medeni Kanunu'nda (ZGB.), kanun koyucu tarafından değişikliğe gidilmeden önce, boşanmada kusursuz veya az kusurlu davacı eşin maddi ve manevi tazminat talebini, $151 \mathrm{vd}$. maddelerinde düzenlenmiştir.

${ }^{14}$ Geniş bilgi için bkz., Cyril, Hegnauer/Peter Breitschmid, Grundriss des Eherechts, Vierte überarbeitete Auflage, Bern 2000, sh. 88.
} 
bazı koşullar öngörmüştür. Kanımızca, kanun koyucunun bu farklıkları öngörmesinin asıl sebebi, boşanmada ortaya çıkan maddi zararın hukuki mahiyetini ve fonksiyonunu, genel anlamda tazminat hukukundan farklı algılamasından kaynaklanmaktadır.

\section{II-Boşanmada Maddi Tazminatın Koşulları.}

Boşanan eşlerin birisinin maddi tazminat talebinde bulunabilmesi için, aşağıda ayrıntılı olarak incelenecek olan koşulların tamamının mevcut olması zorunludur. Aşağıda açıklanacak olan koşulların her hangi birisinin veya bir kaçının mevcut olmaması halinde, boşanan eşlerden kusursuz veya az kusurlu olan tarafin, kusurlu olan diğer taraftan maddi tazminat talebinde bulunması hukuken mümkün değildir.

Kanun koyucu, boşanmada maddi tazminata ilişkin olarak bir takım özel koşullar öngörerek, tazminat hukukunun yapısıyla bağdaşmayan bazı özel koşulların ortaya çıkmasına sebebiyet vermiştir. Bu konulara yeri geldikçe ayrıntılı olarak değinilecektir.

\section{A-Boşanmaya Davalı Tarafın Kusurlu Davranıșı Sebep Olmalıdır.}

Boşanma sonucunda mevcut veya beklenen menfaatleri zarar gören davacı tarafın, karşı taraftan maddi tazminat talebinde bulunabilmesi için, her şeyden önce, davalı tarafin kusurlu olması zorunludur. Kusur, boşanma sonucunda kusursuz veya az kusurlu olan tarafin maddi tazminat talebinin mahkemece kabul edilmesinde en temel koşuldur. Kanun koyucu, bu koşulu, MK. md. 174/I' de “...kusurlu taraftan uygun bir maddi tazminat isteyebilir" şeklinde ifade ederek açıkça belirtmiştir.

Kanun koyucunun MK. md. 174/I' de öngörmüş olduğu kusur kavram1, BK. md. 41'de yer alan kusur kavramından bazı farklılıklar göstermektedir. $\mathrm{Bu}$ farklıkların temel sebebi, daha önce de ifade edildiği gibi, kanun koyucunun, Medeni Kanun'da boşanmada ortaya çıkan maddi tazminata iliş̧in olarak bazı özel koşullar öngörmesinden kaynaklanmaktadır. Zira, boşanmaya sonucunda mevcut veya beklenen menfaatleri zarar gören kusursuz veya az kusurlu olan davacı tarafin, kusurlu olan davalı taraftan maddi tazminat isteyebilmesi için, her şeyden önce, kusurlu davalı tarafin kusurunun yoğunluğun boşanmaya sebep verecek derecede olması gerekir. Diğer bir ifadeyle, boşanmada hakimin maddi tazminata hükmedilebilmesi için, öncelikle, tazminat talebinde bulunan davacının, boşanma davasını Medeni Kanun'da ön görülen kusura dayalı boşanma sebeplerinden ${ }^{15}$ birisine

\footnotetext{
${ }^{15}$ Türk Medeni Kanunu'nda düzenlenmiş olan sınırlı sayıda boşanma nedenleri arasında; zina sebebiyle boşanma ( MK. md. 129), kötü niyetli terk sebebiyle boşanma (MK. md. 132) ve hayata kast veya pek fena muamele nedeniylen boşanma (MK. md. 130), kusura dayalı olan boşanma sebepleridir. Geniş bilgi için bkz., Boşanma ve Ayrılık, Berki, Şakir, AHFD. 1975,
} 
istinaden açmış olması şarttır. Davacı tarafın boşanmada karşı taraftan maddi tazminat alabilmesi için sadece bu koşul da yeterli olmayıp, aynı zamanda, hakimin kusura dayalı olarak ileri sürülen boşanma sebebine istinaden, tarafların boşanmasına karar vermiş olması da gerekir. Dolayısıyla, burada, boşanmaya sebep veren kusurlu davranış veya davranışlarla, boşanma sonucunda maddi tazminata sebebiyet veren kusurlu davranış veya davranışlar arasında işin tabiatı gereği bir aynilik oluşmaktadır. Eğer, boşanmaya sebep olan tarafın kusuru, hakimin boşanmaya karar vermesini gerektirecek derecede yoğun değilse veya anlaşmalı boşanmada tarafların anlaşması hakim tarafından bir şekilde onaylanmamış ve dolayısıyla da tarafların boşanmalarına karar verilememişse, bu durumda, her hangi bir şekilde boşanma sonucunda ortaya çıkan maddi tazminattan bahsedilemez. Kanımızca, bu durumda da, hukuka aykırı davranışından dolayı zarar gören tarafın, Borçlar Kanunu'nun genel hükümlerine göre (BK. md. 41 vd.), zarar verenden maddi tazminat talebinde bulunmasinı engelleyen her hangi bir hüküm yoktur. Ancak, burada mahkemece hükmedilen maddi tazminatla, boşanma sonucunda hükmedilen maddi tazminat aynı değildir.

Kusur, hukuk düzenince kınanan ve hoş görülmeyen bir davranış biçimidirr ${ }^{16}$. Dolayısıyla, kusurlu davranış, kural olarak, hukuka da aykırı olan bir davranıştır. Kusur kavramının iki yönü vardır. Bunlar birincisi, kusurun objektif yönü, diğeri de kusurun sübjektif yönüdür. Kusurun objektif yönü, kusurlu davranan kişinin, aynı şartlar altında dürüst, orta zekal1, makul ve örnek bir tipten beklenen ortalama davranıştan sapma göstermesidir ${ }^{17}$. Kusurun sübjektif yönü ise, kişinin sorumluluk ehliyetiyle ilgilidir $^{18}$. Bir kişinin sorumlu tutulabilmesi için, öncelikle mümeyyiz olması gerekir. MK. md. 15 göre, "kanunda gösterilen ayrık durumlar saklı kalmak üzere, ayırt etme gücü bulunmayan kimselerin fiilleri hukuksal sonuç doğurmaz'". Dolayısıyla, kendisinden tazminat talep edilen tarafin kusur ehliyeti mevcut değilse, bu durumda, boşanmada maddi tazminata hükmedilmesin bahsedilemez. Örneğin, boşanma davasının sebebi akıl hastalığ ise, akı1 hastası olan taraftan, davacı tarafın maddi tazminat talep etmesi hukuken mümkün değildir. Keza, taraflardan her ikisi de aynı derecede kusurlu ise ${ }^{19}$ veya tazminat talebinde bulunan tarafin kusuru,

S. $1-4$, sh. 135 vd.

${ }^{16}$ Oftinger/Stark, Schweizerisches Haftpflichtrecht, Allgemeiner Teil, Bd.1, Zürich 1995, sh. 192; Eren, Fikret, Borçlar Hukuku Genel Hükümler, 7. Bası, İstanbul 2001, sh. 549; Kılıçoğlu, Ahmet, Borçlar Hukuku Genel Hükümler, 3. Bası, Ankara 2003, sh. 199; Oğuzman, Kemal/Öz, Turgut, Borçlar Hukuku Genel Hükümler, 2. Bası, İstanbul 1998, sh. 508.

17 Geniş bilgi için bkz., Schwenzer, Ingeborg, Schweizerisches Obligationenrecht Allgemeiner Teil, 2. überarbeitete Auflage, Bern 2000, sh. 116 vd.; Eren, sh. 554.

18 Geniş bilgi için bkz., Schwenzer, sh. 114 vd.; Oğuzman, Kemal/Öz, Turgut, Borçlar Hukuku Genel Hükümler, 2. Bas1, İstanbul 1998, sh. 512; Eren, sh. 555, 556.

19 Yargitay, aynı derecede kusurlu olan tarafların, birbirinden maddi tazminat talebinde bulunamayacağı yönünde karar vermiştir. Bkz., 2. HD., 1218 E, 1352 K. (Gençcan, Ömer 
boşanma sonucunda ortaya çıan maddi zararla, boşanmaya sebep olan kusurlu davranış arasındaki uygun illiyet bağını kesecek derecede yoğunlukta ise, bu taktirde de, davalı tarafin maddi tazminat talebi doğal olarak ret edilecektir. $\mathrm{Bu}$ sonuç, mantıksal bir zorunluluk olduğu kadar, hukukun genel bir kuralı olan, hiç kimse kusuruna dayanarak hak talep edemez ilkesinin de doğal bir sonucudur.

\section{B-Boşanmada Maddi Tazminat Talep Eden Taraf Kusursuz veya Az Kusurlu Olmalıdır.}

Kanun koyucu, Yeni Medeni Kanun'da, Eski Medeni Kanun'dan farklı olarak $^{20}$, boşanan taraflardan birisinin, diğer taraftan maddi tazminat talebinde bulunabilmesi için, maddi tazminat talep eden tarafin, karşı taraftan kusursuz veya az kusurlu olması koşulunu öngörmüștür. Oysa, Eski Medeni Kanun'da kanun koyucu, boşanan taraflardan birisinin diğerinden maddi tazminat talep edebilmesi için, tazminat talebinde bulunan tarafın, tamamen kusursuz olması koşulunu aranıyordu. $\mathrm{Bu}$ düzenleme, eskiden öğretide önemli bir tartışma konusunu olarak ele alınıyordu. Öğretideki hakim kanaat, düzenlemede yer alan kusursuzluk kavramından mutlak kusursuzluğun anlaşılmaması gerektiği yönündeydi ${ }^{21}$. Zira, boșanma aşamasına gelmiş bir evlilik birliliğinde, sadece taraflardan birisinin kusurlu olduğunu kabul etmek, eşyanın tabiatı gereği pek de mümkün değildir. Dolayısıyla, Eski Medeni Kanun'daki bu düzenleme, boşanma hukukunda maddi tazminat talep edilmesini doğal olarak büyük ölçüde sınırlandırmakta ve bunun pratik sonucu olarak da, bazen, evlilik birliğinin boşanmayla sona ermesinde maddi zarara uğramış tarafın uğradığ 1 maddi zararının tazmin edilememesi gibi adalet duygusunu zedeleyen bir sonuç ortaya çıkmaktaydı.

Oysa, boşanan tarafların kusurlarının yoğunluğu veya derecesi, esas itibariyle, tarafların sorumlu tutulmalarından ziyade, kusurlu davranış sonucunda ortaya çıkan zararın ve dolayısıyla da tayin edilecek tazminat miktarının hesaplanmasıyla ilgilidir ${ }^{22}$.

Ayrıca, boşanan tarafların karşılıklı olarak kusurlu davranışlarıyla birbirlerine maddi zarar vermeleri de her zaman mümkündür. Bu durumda, eğer, zarar görenin kusuru uygun illiyet bağını kesecek yoğunlukta ise, zarar veren sorumluluktan kurtulur ${ }^{23}$. Ancak, zarar görenin kusurlu davranış1

Uğur, 4721 Sayılı Türk Medeni Kanunu, Bilimsel Açıklama İçtihatlar-İlgili Mevzuat, Ankara 2004, sh. 847).

${ }^{20}$ Boşanmada maddi tazminat, EMK. md. 143/I' de, 'Mevcut ve hatta muntazar bir menfaati boșanma yüzünden haleldar olan kabahatsiz karı veya kocanın, kabahatli olan taraftan münasip maddi bir tazminat talebine hakkı vardır" ş̧eklinde düzenlenmiştir.

${ }^{21}$ Bühler/ Spühler, Art. 151, N. 16; BGE 88 II 140.

${ }^{22}$ Öztan, sh. 480; Kılıçoğlu, sh. 16.

${ }^{23}$ Geniş bilgi için bkz., Schwenzer, sh. 109, Eren, sh. 545; Oğuzman/Öz, sh. 506; Kılıçoğlu, (Borçlar) sh. 199. 
uygun illiyet bağını kesmemiş ve sadece zararın doğmasına diğer ortak kusurlarla (illiyetlerle) katkıda bulunmuşsa, bu taktirde, ortak illiyet veya diğer bir ifadeyle, ortak kusurdan bahsedilir ki, bu durumda, sorumluluktan kurtulma değil, tazminat miktarından indirim söz konusu olur ${ }^{24}$.

Netice itibariyle, Yeni Medeni Kanun'da kanun koyucunun, boşanmada maddi tazminat talep eden tarafın mutlak olarak kusursuz olması koşulunu aramaması isabetli bir düzenleme olmuştur. Böylece, evlilik birliğin sona ermesinden dolayı zarar gören kusursuz veya az kusurlu tarafın uğramış olduğu maddi zararının tazmin edilmesi mümkün hale gelmiştir.

\section{C-Boşanma Yüzünden Tazminat Talep Eden Tarafin Mevcut veya Beklenen Menfaatlerin Zedelenmiş Olması Gerekir.}

Boşanan taraflardan kusursuz veya az kusurlu olan davacı tarafın, davalı taraftan maddi tazminat talebinde bulunabilmesi için, ayrıca boşanmadan dolayı mevcut bir menfaatinin yada beklenen bir menfaatinin zarar görmüş (zedelenmiş) olması zorunludur. Kanun maddesinde ifade edilen menfaatlerden maksat, evlilik birliğinin eşlere sağlamıs olduğu veya ileride sağlayacağ 1 varsayılan maddi menfaatlerdir ${ }^{25}$. Yoksa, evlilik birliğinin eşlere sağladığı psikolojik veya duygusal menfaatler, maddi tazminatın konusunu teşkil etmezler.

Kanun koyucu, boşanmada maddi tazminatta mevcut ve beklenen menfaatler kavramlarını öngörerek, tazminat hukukunda farklı bir anlayışın ve dolayısıyla da yeni bazı sorunların ortaya çıkmasına sebebiyet vermiştir. $\mathrm{Bu}$ sorunlar, özellikle, beklenen menfaatler kavramının muhtevasının belirlenmesinde ve dolayısıyla da buna bağlı olarak, tazminat miktarının belirlenmesinde ve ortaya çıkan maddi zararla kusurlu davranış arasında uygun illiyet bağının kurulmasında ortaya çıkar. Kanun koyucu, mevcut veya beklenen menfaatlerin ne anlama geldiğini açıklamamıştır. Kanımızca, kanun koyucunun bu tercihi, bir eksiklik olarak değerlendirilemez. Zira, eşlerin evlilik birliğinde sahip oldukları mevcut veya beklenen menfaatler, zamana, eşlerin kişisel özelliklerine ve önceden öngörülemeyen bir çok faktöre bağlı olarak, hem belirlenmekte hem de sürekli olarak değişmektedir. Dolayısıyla, içi doldurulması gereken ve niteliği itibariyle değişken bir kavram olan menfaat kavramının içeriği, her boșanmada, boşanmanın somut şartları ve boşanan tarafların o anki durumları dikkate alınarak, özenle belirlenmelidir.

Mevcut menfaatlerden maksat, boşanan tarafin evlilik birliği devam etseydi, bundan elde etmeye devam edeceği maddi menfaatlerdir. Kanun koyucu, bu düzenlemeyle, evlilik birliğinin eşler açısından ekonomik gelir

\footnotetext{
${ }^{24}$ Lüchinger/Geizer, Art. 151, N. 4; Eren, sh. 545; Öztan, sh. 480; BGE 115 II.

${ }^{25}$ Geniş bilgi için bkz., Bühler/Spühler, Art. 151, N. 21; Spühler, Art. 151, N. 21.
} 
getiren bir yapı olduğunu da esas itibariyle kabul etmiştir. Filhakika, evlilik birliğinin eşler açısından ekonomik bazı menfaatler getirdiği de bir vakıadır. Ancak, bu ekonomik menfaatlerin neler olduğunu tespit etmek ve boşanma sonucunda bunların hangisinin veya hangilerinin ne oranda ve ne surette zedelendiğini veya zarar gördüğünü tespit etmek, hem önemli hem de önemli olduğu kadar da zor bir iştir. Bu konuda, somut olayların çözümünde, mahkemelere ve ortak bir içtihadın oluşması açısında da özellikle Yargıtay'a çok önemli görevler düşmektedir. Zira, içi boş ve dolayısıyla da belli objektif kıstaslarla muhtevası doldurulmamış menfaat kavramı, boşanma hukukunda farklı tazminat koşullarının ve dolayısıyla da farklı tazminat miktarlarının doğmasına sebebiyet verebilir.

Kanun koyucunun, boşanmada kusursuz veya az kusurlu olan tarafın, kusurlu diğer taraftan maddi tazminat talep etmesinde, sadece mevcut menfaatlerinin zedelenmesini değil, aynı zamanda, beklenen menfaatlerinin de zedelenmesini öngörmüştür. Beklenen menfaatlerden maksat, elde edilmiş veya elde edilmekte olan menfaatlerin dışında, evlilik birliği devam etmiş olsayd, kusursuz veya daha az kusurlu olan maddi tazminat talep eden tarafın ileride sağlayacağı bir kısım ekonomik menfaatlerden ibarettir ${ }^{26} . \mathrm{Bu}$ ekonomik menfaatlere örnek olarak, ölüme bağlı tasarruflardan veya lehe yapılan sigorta poliçelerinden doğacak menfaatleri veyahut da kusursuz veya az kusurlu tarafın karşı tarafın iş yerinde çalışmasından elde edeceği ücret gelirlerini sayabiliriz ${ }^{27}$.

Kanun koyucuyu böyle bir düzenleme yapmaya sevk eden temel düşünce, evlenme sözleşmesinin kendine has özelliğidir. Zira, evlilik sözleşmesi, niteliği itibariyle, süreklilik arz eden ve genellikle de eşlerin hayatları boyunca devam eden bir sözleşme ilişkisidir. Dolayısıyla, evlilik birliğinde eşlerin evlilik birliğinden kaynaklanan mevcut maddi menfaatlerinin yanında, işin mahiyeti gereği, gelecekte gerçekleşmesi muhtemel olan bazı maddi menfaatlerin de olması doğaldır. Ancak, bu maddi menfaatlerin gerçekleşmesi, her şeyden önce evlilik birliğinin veya diğer bir ifadeyle, evlilik sözleşmesinin devam etmesi koşuluna bağlıdır ${ }^{28}$. Ancak, gelecekte gerçekleşmesi muhtemel olan söz konusu ekonomik menfaatlerin mutlaka gerçekleşecekmiş gibi algılanması da, kanımızca, her zaman pek doğru bir yaklaşım olarak değerlendirilemez. Zira, hayatın olağan akışı daima değişken ve umulmadık olayları bünyesinde barındırır. Dolayısıyla, geleceğe ilişkin olan ekonomik menfaatler maddi tazminatın konusunu oluşturduğunda hakimin çok dikkatli olması ve ortalama bir çözüm yolu bularak, tazminat miktarını adalet ölçüsünde tayin etmesi, hem

\footnotetext{
${ }^{26}$ Tuor/Schnyder, sh. 175; Öztan, sh. 484; Tekinay, sh. 243; Akıntürk (Boşanma), sh. 187; Köprülü/Kaneti, sh. 192.

${ }^{27}$ Geniş bilgi için bkz., Bühler/Spühler, Art. 151, N. 28; 29, 30; Spühler, Art. 151, N. 27 vd., Akıntürk, sh. 296.; Öztan, sh. 486; Akıntürk, (Boşanma), sh. 187.

${ }^{28}$ Bühler/Spühler, Art. 151, N. 27; Spühler, Art. 151, N. 21; BGE 72 I 102; 84 II 5.
} 
adil çözüm açısından hem de ortaya çıkan zararla bu zarara sebebiyet veren olay veya olaylar arasında uygun illiyet bağının kurulması bakımından fevkalade önem arz eder. Nitekim, kanun koyucu, kanun maddesinde "....uygun bir tazminat isteyebilir" diyerek, bu hususlara dolaylı da olsa işaret etmek istemiştir.

\section{D-Maddi Zararla Boşanma Arasında Uygun İlliyet Bağı Olmalıdır.}

Boşanmada kusursuz veya az kusurlu olan tarafın talep ettiği maddi zarar, boşanmaya sebep olan kusurlu tarafın, yani davalının kusurlu davranışının uygun bir sonucu olmalıdır ${ }^{29}$. Boşanma sonucunda kusursuz veya az kusurlu davacı tarafin mevcut veya beklenen menfaatlerinde her hangi bir zarar doğmuyorsa veya diğer bir ifadeyle, maddi tazminat talep eden tarafın uğradığını iddia ettiği maddi zarar boşanmanın uygun bir sonucu değilse, bu taktirde, boşanmada maddi tazminattan bahsedilemez.

Kanımızca, hakim, boşanma sonucunda maddi tazminata karar verirken, maddi tazminat talep eden tarafın ileri sürmüş olduğu her vakıayı ayrı olarak özenle değerlendirmeye tabi tutmalıdır. Zira, talep edilen maddi tazminata ilişkin olarak ileri sürülen her sebep, boşanmanın neticesinde ortaya çıkan maddi zararın uygun bir sebebi olmayabilir. Örneğin, boşanmadan sonra davalı tarafın milli piyangodan ikramiye kazanması durumunda, boşanmış davacı tarafın beklemece menfaatlerimde kaybım var diyerek, karşı taraftan maddi tazminat talebinde bulunması halinde, boşanan tarafın beklemece haklarıyla mili piyango ikramiyesinin kazanılması arasından her hangi bir uygun bir illiyet bağının olmaması gerekir.

Daha önce de ifade edildiği gibi, boşanmada az kusurlu veya kusursuz olan tarafın boşanma neticesinde mevcut veya beklemece menfaatlerinde ortaya çıkan maddi zararla kusurlu fiil arasında uygun illiyet bağını kurmak, özellikle, beklemece menfaatler yönünden bazı zorlukları da beraberinde getirmektedir. Zira, boşanmış eşlerin ilerde sahip olacakları miras haklarını veya benzeri ekonomik menfaatlerini boşanma neticesinde ortaya çıkan maddi zarar kavramı içerisinde mutlak olarak değerlendirmek, genellikle mümkün olmayabilir. Çünkü, burada dikkate alınan ekonomik menfaatler, esas itibariyle, geleceğe ilişkin olduğu için, bu menfaatlerin gerçekleşmemesi de her zaman muhtemeldir. Dolayısıyla, gelecekte gerçekleşmesi muhtemel olan bir unsurun mutlak olarak gerçekleşmiş gibi varsayılarak, maddi tazminat miktarının tayininde esas alınması, bazen farazi olan bir maddi zararın tazmin edilmesi sonucunu da ortaya çıkarabilir. Kanımızca, gelecekteki ekonomik menfaatler kavramı, her zaman, maddi tazminatın miktarının hesaplanmasında, net ve sağlıklı sonuçlar veren bir kavram olarak değerlendirilemez. Nitekim, genel tazminat hukuku anlayışına

${ }^{29}$ Zevkliler/Acabey/Gökyayla, sh. 966; Öztan; sh. 482; Feyzioğlu, sh. 404; Öztan, sh. 482; Kılıçoğulu, sh. 18. 
göre, hukuka aykırı bir fiil sonucunda bir maddi zarar oluşmuşsa ve bu zararla sonuç arasında da uygun illiyet bağı mevcutsa veya her hangi bir şekilde bu bağ kesilmemişse, o halde, ortaya çıkan maddi zararın tazmin edilmesi gerekir. Ancak, ileride şu olaylar da gerçekleşebilirdi diyerek, maddi tazminata hükmedilmesinde ise, zararla zarara sebebiyet veren olay arasındaki uygun illiyet bağını kurmak, kanımızca, her zaman pek de mümkün olmayabilir.

\section{III-Boșanmada Maddi Tazminatın Talep Edilme Usulü.}

Boşanmaya kusuruyla sebep olan taraf, kusursuz yada az kusurlu olan tarafin mevcut veya beklenen maddi menfaatlerinin her hangi birisine zarar vermişse, kusurlu taraf, hakimin uygun gördüğ̈̈ tazminat miktarını ödemek zorundadır. Boşanma sonucunda zarar gören kusursuz yada az kusurlu olan taraf, uğramış olduğu maddi zararı kural olarak iki şekilde elde edebilir. Bunlardan birincisi, maddi tazminat konusunda karşı tarafla anlaşması, diğeri de, dava yoluyla karşı taraftan maddi tazminatı talep etmesidir. Maddi zarara uğramış olan kusursuz veya az kusurlu tarafin, maddi tazminat talebinde bulunmadan mahkemenin resen maddi tazminata hükmetmesi hukuken mümkün değildir.

Maddi tazminatın nasıl talep edileceği hususu, eskiden beri öğretide tartışıla gelen bir konudur. Önceleri, öğretide bazı yazarlar, maddi tazminatın sadece boşanma davasıyla beraber talep edilebileceğini savunurken $^{30}$, bazıları da, maddi tazminatın boşanma davasıyla da talep edilebileceği gibi, boşanma davası açıldıktan sonra da, ayrı bir davayla talep edilebileceğini savunmaktadırlar ${ }^{31}$. Keza, Yargıtay da, bazı eski kararlarında maddi tazminatın boşanma davasıyla beraber talep edilmesi gerektiğini ifade ederken $^{32}$, aksi yönde de kararları olmuştur ${ }^{33}$. Ayrıca, ögretide, kusursuz veya az kusurlu davacı tarafın karşı taraftan maddi tazminat talebinde bulunabilmesi için, mahkemenin verdiği boşanma kararının kesinleşmesi şartını da arayan yazarlar vardır ${ }^{34}$

Kanımızca, bu tartışmaların Yeni Medeni Kanun'un yürürlüğe girmesiyle artık bir anlamını da kalmamıştır. Zira, kanun koyucu, MK. md.

\footnotetext{
${ }^{30}$ Saymen, Ferit Hakk1/Elbir, Halit Kemal, Türk Medeni Hukuku, C. III, Aile Hukuku, 2. Bas1, İstanbul 1960, sh. 275; Velidedeoğlu, Hıfzı Veldet, Türk Medeni Hukuku, C. II, Aile Hukuku, 5. Bası, İstanbul 1965, sh. 258.

${ }^{31}$ Tekinay, Selahattin Sulhi, Türk Aile Hukuku, 7. Bas1, İstanbul 1990, sh. 256.; Arsebük, Esat, Medeni Hukuk, C. II, Aile Hukuku, Ankara 1940, sh. 794; Köprülü/Kaneti, sh. 196.

32 2. HD. 26.9.1969, 4219 E, 4248 K, Yazıcı, Hilmi/Atasoy, Hasan, Şahıs, Aile ve Miras Hukuku ile ilgili Yargitay Tatbikatı, 1952-1970, Ankara 1970, sh. 358; 2. HD. 24.6.1968, 3479 E, 4207 K., Yazic1/Atasoy, sh. 359.

${ }^{33}$ 2. HD. 11.7.1946, 2377 E., 3248 K. (Olgaç, Sinai, Kazai ve İlmi İçtihatlarla Türk Medeni Kanunu Medenisi, C. 1, 3, Bası Ankara, sh. 273).

${ }^{34}$ Bkz., Öztan, sh. 479, 480.
} 
178' de, “evliliğin boşanma sebebiyle sona ermesinden doğan dava hakları, boşanma hükmünün kesinleșmesinin üzerinden bir yıl geçmekle zaman aşımına uğrar"' demekle, boşanma sonucunda ortaya çıkan maddi tazminata ilişkin talebin hem boşanma davasıyla hem de boşanma davası kesinleştikten sonra bir yıl içinde kullanılabileceğini dolaylı olsa da ifade etmiş olmaktadır. Nitekim, uygulamada maddi tazminat talepleri, genellikle, boşanma davasıyla beraber talep edilmekte ve hakim, boşanma kararı verdikten sonra, maddi tazminata ilişkin olan talebi de ayrıca değerlendirerek, bu talebe ilişkinde bir karar vermektedir ve dolayısıyla da verilen tüm bu kararlar, beraberce Yargitay denetiminden geçmektedir. Netice itibariyle, hakimin maddi tazminat talebine ilișkin olarak her hangi bir karar vermesi için öncelikle, boşanma kararının Yargıtay'ın denetiminden geçerek kesinleşmiş olmasına gerek yoktur.

\section{IV-Boşanmada Maddi Tazminat Miktarının Belirlenmesi.}

Kanun koyucu, boşanmadan dolayı mevcut veya beklenen menfaatleri zedelenen kusursuz yada az kusurlu olan tarafin, kusurlu olan taraftan uygun bir maddi tazminat isteyebileceğini öngörmekle, maddi tazminat miktarının tayin edilmesinde isabetli olarak, hakime geniş bir taktir yetkisi tanımıştır. Kanun koyucunun hakime tanımış olduğu bu geniş taktir yetkisi, hem boşanma hukukunun ihtiyaçlarına daha uygundur hem de boşanan tarafların kusurlarının boşanmaya olan etkisini değerlendirmede daha fonksiyoneldir. Ayrıca, hakime tanınan bu geniş taktir yetkisi, tazminat hukukunun temel amacı olan uğranılan zararın giderilmesi (tazmin edilmesi) fikrine de hizmet eder niteliktedir.

Hakim, maddi zarar miktarının hesaplanmasında, özellikle, hakkaniyeti, tarafların kusurlarının yoğunluğunu, eğitim seviyeleri, yaşlarını, sosyal durumlarını, tekrar bir evlilik yapıp yapamayacaklarını ve tazminat miktarının her hangi bir sebepsiz zenginleşmeye sebebiyet verip vermediğini, özenle dikkate almalıdır ${ }^{35}$. Zira, yukarıda bahsedilen sübjektif kıstaslar, her boşanan taraf için farklı olduğu gibi, aynı zamanda, tazminat miktarının belirlenmesinde de farklı etkiler yapmaktadır. Nitekim, İsviçre öğretisi ve yargısı, tazminat miktarının tespitinde, yukarıda ifade edilen kıstaslara benzer bazı kıstasları geliștirmiștir. Bu kıstasların başında, hakimin öncelikle, Medeni Kanun'un 4. maddesi gereğince (ZGB. Art. 4), hakkaniyete uygun bir tazminat miktarının belirlenmesi gelir ${ }^{36}$. İsviçre Federal Mahkemesi, davalı tarafın ağır kusurunun tazminat miktarının

${ }^{35}$ Lücginge/ Geiser, Art, 151, Nr. 6; Egger (Çağa), Art. 151, N .7, sh. 229; Feyzioğlu, sh. 315; Akıntürk, sh. 296, Öztan, sh. 499.

${ }^{36}$ Geniş bilgi için bak., Bühler/Spühler, Art. 151. N. 32 vd.; Özellikle, Öztan, İsviçre Federal Mahkemesi ve öğretisinin boşanmada maddi tazminatın hesaplanmasına ilişkin olarak geliştirmiş olduğu kıstasları, eserinin 864 nolu dip notunda geniş olarak yer vermiştir. Bkz., Öztan, sh. 487 vd. 
hesaplanmasında önemli bir kıstas olarak ele almıştır ${ }^{37}$. Ayrıca, Federal Mahkeme, tazminat talebinde bululan tarafın yaşını, sağlı durumunu ve evlilik süresini de tazminat miktarının belirlenmesinde dikkate almaktadır ${ }^{38}$.

Daha önce de ifade edildiği gibi, maddi tazminatın miktarının hesaplanmasında en önemli sorun, gelecekte gerçekleşecek ekonomik menfaatlerin zarar görmesine ilişkin olarak yapılan hesaplamalarda ortaya çıkar. Zira, gelecekte gerçekleşecek maddi menfaatlerin rakamsal olarak hesaplanması, daha önce de ifade edildiği gibi, genellikle mevcut maddi menfaatlerin rakamsal olarak hesaplanmasına nazaran işin doğası gereği daha zordur. Bundan dolayı, hakimin, kanun koyucunun kendisine tanıdığ 1 taktir yetkisini yerinde kullanarak, hayatın olağan akışına ters düşmeyecek şekilde uygun bir maddi tazminat miktarını belirlemesi ve dolayısıyla bu tazminat miktarına hükmetmesi gerekir. Filhakika, şu gerçek de göz ardı edilmemelidir ki, hayat ve dolayısıyla da gelecek, herkes açısından belli oranlarda bir risk faktörünü beraberinde taşımaktadır. Bu muhtemel riski, sadece boşanan taraflardan birisine yüklemek, hem hakkaniyet duygusuna hem de hukukun temel ilkelerinden olan menfaat içtihatçılığ 1 ilkesine uygun düşmez.

Hakim, kural olarak, maddi tazminat talebinde bulunan tarafin talep etmiş olduğu miktarı aşan her hangi bir karar veremez (HUMK. md. 74). Keza, Yargıtay da vermiş olduğu bir çok kararında bu hususa açıkça işaret etmektedir $^{39}$. Ancak, hakim, kanun koyucunun kendine tanımış olduğu taktir yetkisini kullanarak ve mevcut delilleri değerlendirerek, her zaman, talep edilen maddi tazminat miktarından daha az bir tazminat miktarına hükmedebilir.

\section{V-Boşanmada Maddi Tazminatın Ödenme Biçimi.}

Kanun koyucu, MK. md. 176/I' de, hakimin, maddi tazminatın toptan veya durumun gereklerine göre, irat biçiminde de ödenmesine karar verilebileceğini düzenlemiştir. Kanun maddesinden de kolayca anlaşıldığ gibi, hakim, maddi tazminatın ödenme biçimine ilişkin olarak karar verirken de, kanun koyucu tarafından geniş bir taktir yetkisiyle donatılmıştır. Hakim, durumun gereklerine bakarak, maddi tazminatın irat veya toptan olarak ödenmesine karar verebilir. Hakim, durumun gereklerini değerlendirirken, sadece maddi tazminat talebinde bulunan tarafın değil, aynı zamanda, tazminat borçlusunun ekonomik ve sosyal şartlarını ve taleplerini de dikkate alarak karar vermesi gerekir. Ancak, uygulamada, mahkemeler, genellikle, maddi tazminatın toptan bir şekilde ödenmesi yönünde karar vermektedir.

\footnotetext{
${ }^{37}$ BGE 95 II 597; 98 II 165; 99 II 358.

${ }^{38}$ BGE 90 II 75.

39 2. HD, 24.09.2003, 10818 E., 11945 K. (Gençcan, sh. 947).
} 
Boşanan tarafların da, maddi tazminatın ödenme şeklini aralarında kararlaştırmaları her zaman mümkündür. Ancak, tarafların bu konuda yapmış olduğu anlaşmanın ayrıca hakim tarafindan da onaylanması yasal bir zorunluluktur. Zira, kanunu koyucu, Medeni Kanun'da, boşanmanın fer'i sonuçlarına ilişkin olarak taraflarca yapılan anlaşmaların hakim tarafından da onaylanmasını, zorunlu bir koşul olarak öngörmüştür (MK. md. 184/5). Kanımızca, boşanan taraflar tarafından maddi tazminatın ödenmesine ilişkin olarak yapılan anlaşma (sözleşme), hukuka aykırı değilse ve tarafların özgür iradesiyle yapıldığı da açıkça anlaşılıyorsa, hakimin söz konusu bu anlaşmayı onaylaması gerekir. Eğer, hakim, boşanan eşlerin yapmış olduğu bu anlaşmayı onaylamazsa, boşanan taraflardan talep olması halinde, MK. md. 176/I gereği, kendisinin durumun gereklerini dikkate alarak, maddi tazminatın ödenmesine ilişkin bir karar vermesi gerekir.

Burada tartışılması gereken en önemli konulardan birisi de, toptan veya irat biçiminde ödenmesine karar verilen maddi tazminatın neyle ödeneceğidir. Diğer bir ifadeyle, maddi tazminatın nakit veya ayni olarak ödenip ödenmeyeceği konusudur. Öğreti ${ }^{40}$ ve yarg1 karalarında ${ }^{41}$, boşanan tarafların aralarında maddi tazminatın ayni olarak ödenmesi hususunda anlaşma yapmaları koşuluyla, maddi tazminatın ayni olarak da ödenebileceği yönünde görüşler vardır. Örneğin, maddi zarara uğramış olan tarafa zirai bir işletmenin veya bir konutun maddi tazminat karşıllı̆ı olarak verilmesi mümkündür ${ }^{42}$.

Bizim de katıldığımız görüşe göre, maddi tazminatın ayni olarak ödenmesi, sadece boşanan tarafların bu konuda anlaşmaları halinde mümkündür. Eğer, boşanan taraflar, tazminat miktarında ve tazminatın nasıl ödeneceği hususunda her hangi bir anlaşmaya varamamışlarsa, mahkemenin bu durumda maddi tazminatı defaten veya irat şeklinde parayla ödenmesi yönünde karar vermesinden başka bir seçeneği yoktur ${ }^{43}$. Eğer, mahkeme, boşanan taraflar arasında maddi tazminatın ayni olarak ödenmesine ilişkin olarak her hangi bir anlaşma olmadan karar verirse, bu taktirde mahkemenin verdiği bu karar, etkisi itibariyle mülkiyet hakkını zedeleyici ve dolayısıyla da tazminat hukukunun amacını aşan bir karar olur. Zira, boşanan eşlerden birisinin mülkiyetinde olan malın diğerinin mülkiyetine mahkeme kararıyla geçmesi hali, maddi zararın tazmin edilmesinde değil kural sadece olarak bazı mal rejimlerinin tasfiyesi sonucunda ortaya çıkar.

40 Lüchinger/Spühler, Art. 151. N. 7; Öztan, sh. 490, Yalçınkaya/Kaleli, sh. 1823; Zevkliler/Acabey/Gökyayla, sh. 967.

${ }^{41}$ BGE 80 II 102.

${ }^{42}$ Lüchinger/Geiser, Art. 151, N. 8; Bühler/Spühler, Art. 151, N. 43; Tuor/Schnyder, sh. 159; Öztan, sh. 490.

${ }^{43}$ Öğretide, hakimin, boşanan tarafların aralarında maddi tazminatın ayni olarak ödenmesi hususunda her hangi bir anlaşmaya varmasa dahi, maddi tazminatın ayni olarak ödenmesine karar verebileceğini savunan yazarlar vardır. Bkz., Özuğur, sh. 1107. 
İrat şeklinde ödenmesine hakim veya boșanan taraflarca karar verilen maddi tazminat, boşanan taraflardan birisinin ölümü, yada alacaklı tarafin yeniden evlenmesi durumunda kendiliğinden sona erer (MK. md. 176/III). İrat şeklinde ödenen maddi tazminat, tazminat alacaklısının evlenmeden fiilen evlenmiş gibi yaşaması, yoksulluğunun ortadan kalkması, yada haysiyetsiz bir hayat sürmesi hallerinde de, mahkeme kararıyla, sona erer (MK. md. 176/III). Kanun koyucu, bu düzenlemeyle, maddi tazminat alacaklısı aleyhine ileri sürülen iddiaların gerçek olup olmadığının tespitinin hakim tarafından yapılmasını amaçlamıştır. Kanımızca, kanun koyucunun bu düzenlemesi, tazminat alacaklısının menfaatinin korunması açısından son derece isabetli olmuştur. Zira, tazminat borçlusu olan taraf, irat şeklinde ödediği tazminat borcundan kurtulmak için veya diğer bir ifadeyle, bu borcunu ödememek için, tazminat alacaklısı taraf hakkında gerçek dışı bazı iddialarda bulunması her zaman mümkündür.

Ancak, kanun koyucunun maddi tazminatın toptan olarak ödenmesinden farklı olarak, maddi tazminatın irat şeklinde ödenmesinde, yukarıda ifade edilen hususları ayrıca öngörmesi, maddi tazminatın ödenmesinde farklı koşulları ve dolayısıyla farklı hukuksal sonuçları da doğurmuştur. $\mathrm{Bu}$ farklı düzenlemeler ve dolayısıyla da farklı hukuksal sonuçlar, kanun koyucunun maddi tazminatın irat şeklinde ödenmesiyle, boşanmada yoksulluk nafakası ödenmesini esas itibariyle, aynı hukuksal nitelikte görmesinden kaynaklanmaktadır. Kanımızca, maddi tazminatın irat şeklinde ödenmesine ilişkin olarak yukarıda açıklanan hususlar, yoksulluk nafakası borcunun ifası açısından isabetli olsa da maddi tazminat borcunun ifası açısından tam olarak yerinde değildir. Zira, maddi tazminat, boşanan taraflardan kusurlu tarafın davranışı neticesinde, kusursuz veya daha az kusurlu olan tarafın maddi zarara uğraması sonucunda öngörülmektedir. Oysa, yukarıda açıklanan koşulların varlığında hakimin kusurlu olan davalı tarafin uygun bir maddi tazminat ödemesini kararlaştırdıktan sonra bile, tazminatın ödenme biçimi, ödenen veya ödenecek olan maddi tazminat miktarında bazı farklılıklar ortaya çıkarmaktadır. Halbuki, ortaya çıkan bu maddi zarar, maddi tazminat alacaklısının kusurlu davranışı sonucunda değil, bilakis, kusuruyla boşanmaya sebebiyet veren tarafin davranışı sonucunda meydana gelmiştir. Ayrıca, boşanan taraflar, boşandıktan sonra hayatlarını istedikleri gibi özgürce yaşabilirler.. Bu onların sahip oldukları kişilik haklarının en doğal bir sonucudur.

Keza, maddi tazminat alacağı, tazminat alacaklısının mal varlığının aktif kısmında yer alan ekonomik bir değerdir. Bu ekonomik değer, sırf tazminatın ödenme biçiminden dolayı veya daha sonra tazminat alacaklısının özel hayatında ortaya çıkan bazı davranışlardan dolayı, borçlunun mamelekinin pasif kısmında buna mukabil alacaklının da mamelekinin aktif kısmında her hangi bir azalmaya yol açmamalıdır. Bu yaklaşım, kanımızca, kural olarak, tazminat hukukunun temel anlayışıyla da pek bağdaşamaz. Bu olumsuz sonuçlar, yukarıda da ifade edildiği gibi, esas itibariyle, kanun 
koyucunun yoksulluk nafakası borcunun hukuksal niteliğiyle maddi tazminat borcunun hukuksal niteliğini aynıymış gibi kabul etmesinden kaynaklanmaktadır. Oysa, yoksulluk nafakasına hükmetmenin koşulları ve amacıyla, boşanma sonucunda ortaya çıkan maddi tazminatın koşulları ve amacı birbirinden tamamen farklıdır.

Kanımızca, kanun koyucu, maddi tazminatın irat şeklinde değil de taksitle ödenmesine imkan tanısaydı, yukarıda ifade dilen olumsuzlukların ve çelişkilerin hiç birisi ortaya çıkmazdı.

Ayrıca, tazminat kavramı ile irat kavramı hukuksal nitelikleri itibariyle de birbirinden tamamen farklı kavramlardır. Tazminat alacağı, bir irat değildir. $\mathrm{Bu}$ alacak, adı üstünde hukuka aykırı davranış sonucunda ortay çıkan zararın tazmin edilmesi için öngörülmüş olan bir alacak hakkıdır.

VI-Boşanmada İrat Şeklinde Ödenen Maddi Tazminat Miktarının Geleceğe İlişkin Olarak Uyarlanması.

Kanun koyucu, MK. md. 176/V' de "hakim, istem halinde irat biçiminde ödenmesine karar verilen maddi tazminat veya nafakanın gelecek yıllarda tarafların sosyal ve ekonomik durumlarına göre ne miktarda ödeneceğinin karara bağlayabilir', diyerek, yeni bir düzenleme getirmiştir. Kanımızca, kanun koyucu bu düzenlemeyi de yaparken de irat şeklinde ödenen maddi tazminatın hukuki mahiyetiyle, irat şeklinde ödenen yoksulluk nafakasının hukuki mahiyetini aynı kabul etmiştir. Nitekim, fikranın kaleme alınış tarzı bile bu fikri destekler mahiyettedir. Zira, konun koyucu, kanun metninde maddi tazminatla yoksulluk nafakasinı beraberce zikretmektedir. Ancak, kanun koyucunun bu yaklaşımı, tazminat hukukuna tamamen yabancıdır. Zira, tazminat hukukunun temelini, kusur ve zarar kavramları oluşturur. Oysa, yoksulluk nafakasının temelinde yatan kavram, kusur ve zarar kavramları değil, aksine, evlilik birliğinin sona ermesinden dolayı, boşanan taraflardan birisinin yoksulluğa düşmesi ve ortaya çıkan bu yoksulluğun da ahlaksal ve sosyal düşüncelerden dolayı, belli ölçüde giderilmeye çalışılmasıdır.

Ayrıca, kanun koyucunun, istem sonucunda irat şeklinde ödenen maddi tazminat miktarını gelecek yıllara ilişkin olarak uyarlarken, tarafların sosyal ve ekonomik durumlarını kıstas olarak alması da, kanımızca, tazminat hukukunun temel anlayışına aykırıdır. Zira, yukarıda da ifade edildiği gibi, irat şeklinde ödenen maddi tazminatın miktarı gelecek yıllara ilişkin olarak uyarlanırken, tarafların kusuru veya uğranılan maddi zararın miktarı dikkate alınarak yapılmadığından, uyarlama sonucunda, önceden belirlenmiş maddi zarar miktarından tamamen farklı, yeni bir maddi tazminat miktarları ortaya çıkmaktadır ki, bunun da tazminat hukuku açısından istenilen bir sonuç olmadığı açıktır. Kanımızca, olması gereken hukuk açısından bu düzenlemenin değiştirilmesi daha isabetli olur. Filhakika, daha önce de ifade 
edildiği gibi, maddi tazminatın irat olarak ödenmesinden değil, olsa olsa tazminat miktarının vadeye bağlanarak taksitle ödenmesinden bahsedilebilir. Taksite bağlanmış olan maddi tazminat alacağına kanuni faiz oranları uygulanarak da, kolayca bir ödeme planı oluşturulabilir.

VII-Boşanmada İrat Şeklinde Ödenen Maddi Tazminat Miktarının Hakim Kararıyla Değiştirilmesi.

Daha önce de ifade edildiği gibi, kanun koyucu, MK. md. 176/I' de, maddi tazminatın irat biçiminde de ödenebileceğini düzenlemiştir. Ayrıca, kanun koyucu, MK. md. 176/III' de, taraflarmn mali durumlarının değişmesi veya hakkaniyetin gerektirdiği hallerde iradın artırılması veya azaltılmasına karar verebilir" diyerek, dolayısıyla irat şeklinde ödenmesine karar verilen maddi tazminat miktarının da zaman içerisinde tarafların maddi durumlarının değişmesi veya hakkaniyetin gerektirdiği hallerde değişebileceğini düzenlemiş olmaktadır.

Kanun koyucu, bu düzenlemeyi de yaparken, yukarıda da ifade edildiği gibi, esas itibariyle, yoksulluk nafakasının dayandığı temel düşünceden hareket etmiştir. Zira, maddi tazminatın miktarının belirlenmesi, daha önce bir çok kez ifade edildiği gibi, zaman içerisinde tarafların mali durumlarının değişmesi veya hakkaniyetin gerektirmesiyle ilgili her hangi bir sorun olmayıp, bilakis, tazminat alacaklısının uğradığı maddi zararın miktarı ve zarar verenin kusurunun ağırlığıyla ilgili bir sorundur. Netice itibariyle, yasadaki bu düzenleme, boşanmada maddi tazminat söz konusu olduğunda, maddi tazminatın ödenme şeklinin farklı bir şekilde belirlenmesi yoluyla, zaman içerisinde birbirinden farklı maddi tazminat miktarlarının ortaya çıkmasına ve dolayısıyla da farklı maddi tazminat miktarlarının ödenmesine sebep olacaktır. Bu da, daha önce de ifade edildiği gibi, tazminat hukukunun temel anlayışına uygun olmayan bir sonuçtur.

\section{Ermesi.}

VIII-Boşanmada İrat Şeklinde Ödenen Maddi Tazminatın Sona

Kanun koyucu, MK. md. 176/III' de, irat şeklinde ödenmesine karar verilen maddi tazminatın belli koşullar altında kendiliğinden ortadan kalkacağını, bazı koşullar altında da mahkeme kararıyla kaldırılacağını hükme bağlamıştır.

A-Boşanmada Irat Şeklinde Ödenen Maddi Tazminatın Kendiliğinden Sona Ermesi.

Kanun koyucu, MK. md. 176/III' ün birinci cümlesinde, irat şeklinde ödenmesine karar verilen maddi tazminatın, maddi tazminat alacaklısının yeniden evlenmesi veya taraflardan birisinin ölümü halinde kendiliğinden sona ereceğini düzenlenmiştir. 
Kanımızca, kanun koyucunun bu düzenlemesi de esas itibariyle, tazminat hukukunun temel yaklaşımına uymamaktadır. Zira, daha önce de bir çok kez ifade edildiği gibi, kanun koyucu, maddi tazminatın irat olarak ödenmesini yoksulluk nafakasının irat olarak ödenmesindeki temel düşünceyi esas alarak düzenlemiştir. Oysa, maddi tazminatın dayandığı hukuksal gerekçeler ve sebeplerle, yoksulluk nafakanın dayandığı hukuksal gerekçeler ve sebepler daha önce ifade edildiği gibi, birbirinden tamamen farklıdır. Boşanma sonucunda maddi tazminatın kurucu unsuru, zarar ve zarar verenin kusuru iken, yoksulluk nafakasının öngörülmesinde temel alınan fikir, boşanma sonucunda taraflardan birisinin yoksulluğa düşmesidir. Kanun koyucu, tazminat hukukuna yabancı olan bazı koşulların varlığında tazminat borcunun kendiliğinden ortadan kalkacağını düzenlemekle, kusurlu olan tazminat borçlusunu tazminatla ilgisi olmayan başka sebeplerden dolayı, borcunu ödemekten kurtarmış olmakta ve dolaysıyla da, maddi tazminat alacaklısı bir anlamda cezalandırılmış olmaktadır. Kanımızca, olması gereken hukuk açısından bu düzenlemenin de değiştirilmesi ve tazminat hukukunun mahiyetine uygun hale getirilmesi gerekir.

\section{B-Boşanmada İrat Şeklinde Ödenen Maddi Tazminatın Mahkeme Kararıyla Kaldırılması.}

Kanunu koyucu, MK. md. 176/III' ün ikinci cümlesinde, maddi tazminat alacaklısının, evlenmeden, fiilen evliymiş gibi yaşaması, yoksulluğunun ortadan kalkması yada haysiyetsiz hayat sürmesi durumlarında, tazminat alacağının mahkeme kararıyla ortadan kalkacağını düzenlemiştir. Kanımızca, kanun koyucunun bu düzenlemesi de tazminat hukukuna aykırıdır. Zira, daha önce de ifade edildiği gibi, hukuka aykırı bir fiil neticesinde hükmedilen maddi tazminat, esas itibariyle, zarar görenin zararını karşılamayı amaçlar. Kanun koyucu, bu düzenlemede de, maddi tazminatın irat şeklinde ödenmesiyle, yoksulluk nafakasının irat şeklinde ödenmesini aynı hukuksal mahiyette kabul etmiştir. Oysa, boşanan ve maddi tazminat alacaklısı olan tarafın özel hayatının veya taraflardan birisinin ölmesinin veyahut da yoksulluğun ortadan kalmasının tazminat borcunun ödenmesiyle her hangi bir ilgisinin olmaması gerekir.

\section{IX-Boşanmada Maddi Tazminatta Zaman Aşımı.}

Kanun koyucu, Yeni Medeni Kanun'da, boşanma sonucunda taraflar lehine doğan dava hakları için, Eski Medeni Kanun'dan farklı olarak, yeni bir düzenlemeye gitmiştir. Bu düzenlemeye göre, boşanma sonucunda lehine dava hakkı doğan taraf, boşanma kesinleştikten sonra, bir yıl zarfinda, bu haklarını dava yoluyla talep edebilirler (MK. md. 178). Kanımızca, kanun koyucu, Medeni Kanun'da bu hükmü koymakla, isabetli hareket etmiştir. Zira, kanun koyucu, bu düzenlemeyle, Medeni Kanun'da boşanma 
hukukunda zaman aşımına ilişkin olarak, hem yeknesak bir kural geliştirmiş hem de zaman aşımı süresini kısa tutarak, boşanan eşlerin uzun süre birbirleriyle uğraşmalarının yolunu kesmiştir. Filhakika, boşanmayla ortak yaşamlarına son vermiş tarafların, yaşamlarını yeniden düzenlemekleri ve birbirleriyle olan anlaşmazlıklarını da kısa sürede çözmeleri, öncelikle kendi menfaatlerinin bir gereğidir.

Öğretide, kanun maddesinin kenar başlığının zaman aşımı yerine hak düşürücü süre olmasının daha isabetli olacağını ileri süren yazarlar vardır ${ }^{44}$. Ancak, kanun koyucu, kanun maddesinin kenar başlı̆̆ını zaman aşımı olarak nitelendirdiği için pozitif hukuk anlayışı gereği, buradaki sürenin zaman aşımı süresi olarak kabul edilmesi bir zorunluluktur. Kanun maddesinde yer alan sürenin zaman aşımı veya hak düşürücü süre olmasının en önemli farkı, eğer, bu süre hak düşürücü süre olarak kabul edilseydi, hakimin bu sürenin sona erip ermediğinin resen dikkate alması gerekirdi. Ancak, kanun maddesinde yer alan süre zaman aşımı süresi olduğu için, bu sürenin sona erip ermediği hakim tarafindan resen dikkate alınması gerekmez. Dolayısıyla, boşanma davası kesinleştikten bir yıl sonra, her hangi bir maddi tazminat talebiyle karşılaşan taraf, öncelikle zaman aşımı definde bulunmak zorundadır. Aksi taktirde, mahkemede ilk itiraz ${ }^{45}$ olarak zaman aşımı definde bulunmazsa, boşanmadan kaynaklanan maddi tazminat talebiyle karşı karşıya kalacaktır.

Biz de, olması gereken hukuk açısından, bu sürenin zaman aşımı süresi yerine, hak düşürücü süre olarak düzenlenmesinin daha isabetli olacağ 1 görüşündeyiz. Zira, boşanma sonucunda taraflar, birbirlerinden mümkün mertebe çabuk kopmalı ve boşanmanın sonuçlarına ilişkin haklarını da mümkün mertebe kısa sürede kullanmalıdırlar.

\section{4-BOŞANMADA MANEVI TAZMIINAT.}

\section{I-Genel Olarak.}

Kanun koyucu, Medeni Kanun'da, boşanmada maddi tazminatla beraber manevi tazminatı da düzenlemiştir. Zira, boşanma durumunda, boşanan tarafların sadece mevcut veya gelecekteki maddi menfaatleri değil, aynı zamanda, kişilik hakları da zarar görebilir. Filhakika, eşleri boşanmaya götüren boşanma sebepleri, genellikle, eşlerin kişilik haklarına da zarar vererek, onların üzülmesine ve sonuç olarak da onların acı ve ıstırap çekmesine neden olur. Pek tabidir ki, eşlerin kişilik haklarının ihlal edilmesinden dolayı duydukları bu 1stırap ve acinın biraz olsun hafifletilmesi, manevi zarara uğramış olan tarafa, karşı taraftan manevi tazminat isteme hakkının verilmesiyle mümkün olur.

\footnotetext{
${ }^{44}$ Kılıçoğlu, sh. 19.

${ }^{45}$ Geniş bilgi için bkz., Baki, Kuru/Ramazan, Arslan/Ejder, Yılmaz; Medeni Usul Hukuku, Genişletilmiş 15. Bası, Ankara 2004, sh. 320.
} 
Kanun koyucu, Medeni Kanun'da, boşanmada maddi tazminatta olduğu gibi, aynı şekilde manevi tazminatta da özel bir düzenlemeye gitme ihtiyacını duymuştur. Boşanmada maddi tazminatın Medeni Kanun'da özel olarak düzenlenmesine ilişkin olarak ileri sürülen eleştiriler ve görüşler boşanmada manevi tazminatın Medeni Kanun'da özel olarak düzenlenmesi için de aynen geçerlidir.

\section{II-Boşanmada Manevi Tazminatın Koşulları.}

Boşanan taraflardan birisinin, diğerinden manevi tazminat talep edebilmesi için, MK. md. 174/II göre, aşağıda ayrıntılı olarak incelenecek olan koşulların mevcut olması gerekir. Eğer, söz konusu bu koşullardan her hangi birisi veya birden fazlası mevcut değilse, boşanmada manevi tazminattan söz edilemez. Medeni Kanun'daki boşanmanın mali sonuçlarına ilişkin olarak düzenlenen bu hükümler, Medeni Kanun'un 24. maddesinde ${ }^{46}$ ve Borçlar Kanunu'nun 49. maddesinde düzenlenen manevi zarar hükümlerine nazaran özel hüküm niteliğindedir.

\section{A-Taraflar Boşanmış Olmalıdır.}

Boşanma sonucunda boşanmaya sebep olan kusurlu taraftan kişilik hakkı saldırıya uğrayan ve dolaysıyla kişilik hakları zarar gören tarafın tazminat talebinin kabul edilebilmesi için her şeyden önce, tarafların boşanmasına mahkemece karar verilmiş olması zorunludur. Bu hususa kanun koyucu, MK. md. 174/II' de "Boşanmaya sebep olan olaylar:..." ifadesiyle işaret etmektedir.

Öğretide bazı yazarlar ${ }^{47}$ bu ifadeyi mahkemenin verdiği kararın kesinleşmesi olarak anlasa da burada kast olunan, mahkemenin vermiş olduğu kararın kesinleşmesi değildir. Burada kast edilen husus, boşanma ve manevi tazminat talebinin beraber olarak mahkemeden talep edildiğinde, hakimin, önce boşanma kararını vermesi daha sonra da boşanmaya sebebiyet veren davalı tarafın kusurlu davranış veya davranışlarının boşanan davacı tarafin şahsiyet haklarına her hangi bir zarar verip vermediği konusunda hususunda karar vermesidir.

Ayrıca, boşanma davası kesinleştikten sonra da, MK. md. 178 göre, boşanma sonucunda manevi zarara uğramış olan taraf, koşulları mevcutsa diğer taraftan bir yıl zarfında da manevi tazminat talebinde bulunabilir.

\footnotetext{
46 Öztan, Medeni Kanun'un 174 maddesinin ikinci fikrasının Medeni Kanun'un 24. maddesinin özel bir uygulama alanı olduğunu söylemektedir, Bkz., Öztan, sh. 493.

${ }^{47}$ Öztan, sh. 480.
} 


\section{B-Manevi Tazminat Talep Eden Tarafın Kişilik Hakkının Boşanma Sonucunda İhlal Edilmiş Olması Gerekir.}

Tek başına boşanma kararı, boşanan taraflara karşı taraftan manevi tazminat talep etme hakkı vermez. Boşanma halinde manevi tazminatın söz konusu olabilmesi için, boşanan taraflardan davacı tarafın kişilik hakkının boşanmaya sebep olan olaylar neticesinde zarar görmüş olması zorunludur. Ancak, boşanmaya sebebiyet veren olayların manevi tazminat talep eden tarafın kişilik hakkını ihlal edip etmediğin tespit edilmesi de, her zaman kolay bir iş değildir. Zira, her olayın kişilerin duygusal yaşamlarında bıraktığı iz ve etki bir birinden farklılık gösteriri. Keza, kișilerin acı duyma eşiği, duygularını dişarıya yansıtma biçimi ve olaylardan etkilenmesi de, genellikle kişiden kişiye faklılıklar gösterir. Dolayısıyla, boşanmaya sebebiyet veren olayların boşanan davacı tarafın kişilik hakkını zedelediğinde ortaya çıkan manevi tazminat miktarının hesaplanmasında, ortak ve standart kıstasların tespit edilmesi, işin mahiyeti gereği genellikle çok zordur ${ }^{48}$.

Kanun koyucu, Eski Medeni Kanun'dan farklı olarak (EMK. md. 143/II), Yeni Medeni Kanun'da, kişilik hakkının "ağır surette" ihlali koşulunu aramamıştır. Kanımızca, kanun koyucunun bu yaklaşımı isabetlidir. Zira, boşanma sonucunda kusursuz veya az kusurlu olan davacı tarafın kişilik haklarının ağır surette ihlal edilmesi ve bundan dolayı da davacı tarafin manevi zarar görmesi, kusurlu tarafın sorumlu tutulmasından ziyade, manevi zarar miktarının hesaplanmasıyla ilgili bir sorundur. Eğer, boşanan taraflardan boşanmaya sebebiyet veren tarafin kusurlu davranışıyla, manevi zarar gören tarafın uğradığı manevi zarar arasında uygun bir illiyet bağı kurulmuşsa, bu taktirde, kusurlu taraf sorumlu demektir. Ayrıca, kişilik hakkının ağır surette ihlal edilmesine de gerek yoktur.

\section{C-Boşanmaya Sebep Olan Kusurlu Tarafın Davranışın Karşı Tarafın Kișilik Hakkına Zarar Vermiș Olması Gerekir.}

Boşanmada kişilik hakkı ihlal olunan taraf, karşı taraftan manevi tazminat talebinde bulunabilmesi için, ayrıca, boşanmaya sebebiyet veren tarafın kusurlu olması da lazımdır. Buradaki kusurdan maksat, boşanmaya sebep olacak yoğunlukta olan kusurdur. Diğer bir ifadeyle, Medeni Kanun'da ön görülen kusura dayalı boşanma sebepleri sonucunda, boşanan kişinin kişilik haklarının ihlal edilmiş olması gerekir.

Kanun koyucu, Yeni Medeni Kanun'da, kusurun niteliği hususunda her hangi bir ayrıma gitmeyerek isabetli davranmıştır. Zira, burada aranan kusur, hakimin boşanma kararını vermesine yetecek derecede olan kusurdur.

\footnotetext{
${ }^{48}$ Geniş bilgi için bkz., Gürsoy, Kemal Tahir, Manevi Zarar ve Tazmini, AHFD. 1972, S. 1, sh. 7 vd.
} 
Davalının kusurunun özel ağırlı̆̆ı, daha önce de ifade edildiği gibi, manevi tazminatın hükmedilmesine ilişkin olmayıp, daha ziyade, tazminat miktarının hesaplanmasıyla ilgili bir sorundur.

Öğretide bazı yazarlar ${ }^{49}$, kanun koyucunun MK. md. 174/II' de hukuka aykırılık unsuruna yer vermediğini, bunun yerine boşanmanın kesinleşmiş olması şartını aradığını savunsalar da, biz, bu fikre katılmıyoruz. Zira, yukarıda da ifade edildiği gibi, kanun koyucu, ilgili kanun maddesinde hukuka aykırılığa ve dolayısıyla boşanmaya sebebiyet verenin kusura dolaylı olarak işaret etmiştir. Ayrıca, bizim hukukumuzda, boşanma nedenleri Medeni Kanun'da sınırlı sayıda sayılmış ve bu sebeplerin ekseriyeti de boşanan tarafların kusurlu olmasına bağlanmıştır. Ayrıca, bu görüş esas alınırsa, kusur ehliyeti olmayan boşanan tarafları da manevi tazminat ödemeye mahkum etmek gerekir ki, bu tür bir yaklaşım kusur sorumluğunun sınırlarını aşar.

Kanun koyucu, MK. md. 174/II' de, manevi tazminat isteminde bulunan tarafın kusursuz yada az kusurlu olmasından da bahsetmemiştir. Kanımızca, kanun koyucunun bundan bahsetmemesi, bir eksiklik olarak değerlendirilmemelidir. Zira, tazminat hukukunun genel ilkelerinin (BK. md. 49. vd.) ve MK. md. 174/I' in kiyas yoluyla uygulanması sonucunda, kusursuz veya az kusurlu olan tarafın uğradığı bir manevi zararı varsa, boşanmaya sebep olan kusurlu taraftan, her zaman manevi tazminat talebinde bulunabilir. Yeter ki, manevi tazminat talebinde bulunan tarafin kusuru, ortaya çıkan zararla karşı tarafın kusurlu fiili arasındaki uygun illiyet bağını kesecek yoğunlukta olmasın.

\section{D-Uğranılan Manevi Zararla Boşanmaya Sebep Olan Kusurlu Tarafın Davranışı Arasında Uygun İlliyet Bağının Bulunması Gerekir.}

Davacının kişilik haklarına zarar verdiğini iddia ettiği ve boşanmaya da sebep olan karşı tarafın kusurlu davranışı, manevi zararın uygun bir sonucu olmalıdır. Eğer, boşanan davacı tarafın uğradığı manevi zararla, boşanma olayı arasında uygun illiyet bağı yoksa, bu taktirde, boşanan davalı tarafın manevi tazminat ödemesine gerek yoktur.. Örneğin, boşanan taraflardan birisi, boşandıktan sonra, boşanmaya sebep olan kusurlu davranışlardan dolay1 değil de, işlerinin kötü gitmesinden kaynaklanan üzüntüden dolayı psikolojik bir rahatsızlık geçirmişse ve bu rahatsızlığından dolayı da boşanma kararı kesinleştikten sonra bir yıl zarfında karşı taratan her hangi bir manevi tazminat talebinde bulunmuşsa, bu tazminat talebinin ret edilmesi gerekir. Zira, bu örnekte anlatılan olayda, boşanan tarafın düşmüş olduğu psikolojik rahatsızlık durumuyla boşanmaya sebebiyet veren olaylar arasında uygun illiyet bağı anlamında her hangi bir nedensellik yoktur.

\footnotetext{
${ }^{49}$ Öztan, sh. 474.
} 
Ancak, bazı boşanma sebeplerinde, boşanma sebebiyle boşanan tarafın uğradığı manevi zarar arasında uygun illiyet bağı kurmak kolaydır. Örneğin, eşin zina etmesinde, ${ }^{50}$ eşin cana kast etmesinde veya pek fena muamelede bulunmasında, bu nedensellik bağ 1 kolayca kurulabilir.

\section{III-Boşanmada Manevi Tazminatın Talep Edilme Usulü.}

Boşanmaya kusuruyla sebep olan ve dolayısıyla da karşı tarafın manevi zarar görmesine neden olan taraf, neden olduğu bu manevi zararı tazmin etmek zorundadır. Kural olarak, manevi zarara uğramış olan taraf, manevi zararını ya karşı tarafla anlaşarak, yada dava yoluyla bu zararının karşı taraftan talep ederek giderebilir. Eğer, manevi zarara uğrayan kusursuz veya az kusurlu olan taraf, manevi tazminat talebinde bulunmamışsa, mahkeme tarafindan bu konuda resen her hangi bir karar verilemez.

Dava yoluyla maddi tazminatın talep edilmesi konusunda, 22.1.1988 Tarihli İçtihadı Birleştirme Kararı'ndan önce, öğreti görüşlerinde ve yargı kararlarında her hangi bir fikir birliği yoktu. Yargıtay, verdiği içtihadı birleștirme kararında, 'boşanma hükmünün kesinleşmesinden sonra dahi kabahatsiz eşin boşanmaya neden olan olaylara dayanarak manevi tazminat davası açabileceğini"“ ifade etmiştir. Eski Medeni Kanun yürürlükte iken, Yargıtay'ın vermiş olduğu bu İçtihadı Birleştirme Kararı, son derece isabetli ve yerinde olan bir karard1. Zira, Yargitay, verdiği bu kararıyla, hem farklı uygulamalara son vermiştir hem de hak arama özgürlügün önündeki bir engelleri ortadan kaldırmıştır.

Kanımızca, yukarıda bahsedilen tartışmalar, Yeni Medeni Kanun'un yürürlüğe girmesiyle, artık anlamını tamamen yitirmiştir. Zira, kanun koyucu, Yeni Medeni Kanun'da, manevi tazminatın boşanma davasıyla birlikte veya ayrı olarak talep edilebileceğine ilişkin olarak doğrudan doğruya bir düzenleme öngörmemesine rağmen, bu konuya maddi tazminatın talep edilmesinde de olduğu gibi, dolaylı bir çözüm getirmiştir. Zira, Kanun koyucu, MK. md. 178' de, 'Evliliğin boşanma sebebiyle sona ermesinden doğan dava hakları, boşanma hükmünün kesinleşmesinin üzerinden bir yıl geçmekle zaman aşımına uğrar" demekle, evliliğin boşanma sebebiyle sona ermesinden doğan manevi tazminata ilişkin dava hakkının da, davanın kesinleşme tarihinden itibaren bir yıl içerisinde zaman aşımına uğrayacağını düzenleşmiş olmaktadır.

\section{IV-Boşanmada Manevi Tazminatın Miktarı.}

Kişilik hakkında meydana gelen eksilmenin hesaplanması, işin mahiyeti gereği, maddi zararların hesaplanmasına nazaran genellikle daha zordur.

\footnotetext{
${ }^{50}$ Örnek için bak., Kılıçoğlu, sh. 18.
} 
Zira, ihlal edilen kişilik haklarının her hangi bir piyasa değerinin olmaması, ve kişilerin bu değerlerinin ihlalinde duydukları açı ve 1stırabın kişiye göre farklılık arz etmesi, manevi zararın miktarının hesaplanmasını da doğal olarak zorlaştırmaktadır. Nitekim, bu düşüncelerden hareket eden kanun koyucu da, MK. md. 174/II' de, 'boşanmaya sebep olan olaylar yüzünden kişilik hakkı saldırıya uğrayan taraf, kusurlu olan diğer taraftan manevi tazminat olarak uygun miktarda bir para ödenmesini isteyebilir" diyerek, bu konuda hakime geniş bir taktir yetkisi tanımıştır. Kanun koyucu, Medeni Kanun'da manevi tazminat için uygun miktar paranın ödenmesinde hangi kriterlerin dikkate alınacağına ilişkin olarak her hangi bir kural öngörmemiştir. Kanımızca, kanunda bu konuda ayrıntılı bir düzenlemenin ve somut kriterlerin olmaması, önemli bir eksiklik olarak da değerlendirilemez. Zira, hakim, uygun miktarda tazminatı belirlerken, BK. md. 49' de öngörülmüş olan kıstasları da kıyas yoluyla uygulayarak, tarafların sıfatını, işgal ettikleri makamı ve diğer sosyal ve ekonomik durumlarını dikkate alarak, hakkaniyete ${ }^{51}$ uygun bir manevi tazminat miktarına hükmedecektir.

\section{V-Boşanmada Manevi Tazminatın Ödenme Biçimi.}

Kanun koyucu, Medeni Kanun'da manevi tazminatın nasıl ödeneceğini açıkça düzenlemiştir. MK. md. 176/II' göre, "manevi tazminatın irat biçiminde ödenmesine karar verilemez ${ }^{6}$. Bu düzenlemeden de kolayca anlaşılabildiği gibi, manevi tazminat bir defada, toptan olarak, parayla hak sahibine ödenecektir. Dolayısıyla, manevi tazminatın ayni olarak ödenmesi kanunen mümkün değildir.

Kanımızca, kanun koyucunun boşanmada hükmedilen manevi tazminata ilişkin düzenlemesi, esas itibariyle, tazminat hukukunun amacina daha uygun bir düzenlemedir. Zira, tazminat alacağı, daha önce de ifade edildiği gibi, zarar görenin mal varlığının aktif kısmında yer alan bir alacaktır. Bu alacağın irat olarak değerlendirilmesi, işin mahiyeti gereği doğru olmazdı. Keza, maddi tazminat alacağı ile manevi tazminat alacağının hukuksal niteliği birbirinden de farkı değildir. Zira, her iki tazminatı doğuran hukuksal sebeplerin farklı olması, sonuç olarak, ortaya çıkan tazminat alacağının hukuksal niteliğinin farklı olduğu anlamına gelmez.

Ayrıca, kanımızca, olması gereken hukuk açısından, manevi tazminat alacağının tarafların ekonomik durumları veya aralarında anlaşmaları gibi hususlar dikkate alınarak, taksitler halinde ödenmesin düzenlenmesi yerinde olur.

\footnotetext{
51 Yargıtay da, manevi zarar miktarının belirlenmesinde, hakimin, hakkaniyete uygun davranması gerektiği görüşündedir. Bkz., 2. HD. 1986, 9713 E., 10108 K.,(internet).
} 
Burada akla gelen diğer bir soru, manevi tazminatın ayni olarak ödenip ödenemeyeceğidir. Daha önce maddi tazminatın ödenmesine ilişkin olarak ifade edilen görüşler, manevi tazminatın da ödenmesi açısından geçerlidir. Eğer, boşanan taraflar, aralarında anlaşıp, manevi zarara uğrayanın zararının tazmin edilmesinde ödeme aracı olarak bir malın mülkiyetinin devredilmesini kararlaştırmışlarsa, bu taktirde, kanımızca, hakimin tarafların bu kararını onaylaması gerekir. Ancak, boşanan taraflar, manevi zararın nasıl ödeneceği hususunda her hangi bir anlaşmaya varmamışlarsa, bu durumda, hakimin manevi tazminatın sadece parayla bir defada toptan olarak ödenmesi yönünde bir karar vermesinden başka seçeneği yoktur. Aksine bir çözüm, kanuna aykırı olur.

\section{VI-Boşanmada Manevi Tazminatta Zaman Aşımı.}

Kanun koyucu, boşanmada manevi tazminat için ayrı bir zaman aşımı süresi öngörmemiştir. MK. md. 178 ‘ de ön görülen bir yıllık zaman aşımı süresi, manevi tazminat talebi için de geçerlidir. Kanımızca, daha önce ifade ettiğimiz sebeplerden dolayı, kanun koyucunun hem zaman aşımı süresi olarak bir yıl görmesi, hem de evliliğin boşanma sebebiyle sona ermesinden doğan dava hakları arasında zaman aşımı süresi bakımından her hangi bir ayrım yapmaması isabetli olmuştur. Keza, bu sürenin hak düşürücü süre olarak düzenlenmesi, daha önce ifade ettiğimiz gerekçelerden dolayı daha isabetli olurdu.

\section{İKİNCİ BÖLÜM. \\ BOŞANMADA YOKSULLUK NAFAKASI. 5-GENEL OLARAK.}

Kanun koyucu, Medeni Kanun'da, boşanmanın mali sonuçları arasında, maddi ve manevi tazminatla beraber yoksulluk nafakasını da öngörmüştür. Yoksulluk nafakası, boşanmada talep edilen maddi ve manevi tazminattan dayandığ 1 temel düşünce itibariyle tamamen farklıdır. Boşanmada maddi ve manevi tazminata hükmedilmesi veya hükmedilmemesi, mutlaka yoksulluk nafakasına da hükmedilmeyeceği anlamına gelmez. Zira, daha önce de ifade edildiği gibi, boşanmada maddi veya manevi tazminata hükmedilmesin temel amacı ve koşullarıyla, yoksulluk nafakasına hükmedilmesinin temel amacı ve koşulları, genellikle birbirinden farklıdır. Boşanmada maddi ve manevi tazminata hükmedilmesinin temel sebebi, boşanan taraflardan kusursuz veya az kusurlu olan tarafin, karşı tarafin kusurlu davranışıyla boşanmaya sebebiyet vermesi neticesinde uğramış olduğu maddi veya manevi zararların tazmin edilerek giderilmesidir. Oysa, yoksulluk nafakasının dayandığı temel düşünce, esas itibariyle, boşanan taraflardan birisinin boşanma sonucunda düşmüş olduğu yoksulluk halinin sosyal 
dayanışma fikri ve ahlaksal değerler gereğince nispeten giderilmeye çalışılmasıdır ${ }^{52}$.

Evlilik birliğinin sona ermesiyle, boşanan taraflardan birisinin yoksulluğa düşmesi genellikle muhtemeldir. Ülkemizde boşanmada yoksulluğa düşen taraf, ülkenin sosyal ve ekonomik yapısından dolayı, genellikle kadınlar olmaktadır. Ancak, kanun koyucu, Yeni Medeni Kanun'da yoksulluk nafakası hükümlerini düzenlerden, Eski Medeni Kanun'un sisteminden ${ }^{53}$ ayrılarak, kadın ve erkek ayrımı yapmamıştır. Kanun koyucunun bu tercihi, kural olarak, hem evrensel hukuka ${ }^{54}$ hem de anayasamızın $^{55}$ ruhuna daha uygundur. Zira, yoksulluk nafakasının temelinde, cinsiyet değil, bilakis, boşanan taraflardan birisinin boşanma sonucunda düşmüş olduğu yoksulluk problemi yatmaktadır.

\section{6-YOKSULLUK NAFAKASININ KOŞULLARI.}

Her boşanma sonucunda, kural olarak, yoksulluk nafakasına hükmedilmesi gerekmez. Hakimin, boşanan taraflardan birisini lehine yoksulluk nafakasına hükmedebilmesi için, Medeni Kanun'da öngörmüş olan koşulların tamamının gerçekleşmiş olması gerekir. Bu koşullardan her hangi birisinin mevcut olmaması halinde hakim, yoksulluk nafakasina hükmedemez.

\section{I-Yoksulluk Nafakası Talep Edilmiş Olmalıdır.}

Hakimin yoksulluk nafakasını boşanan taraflardan birisi lehine hükmedebilmesi için, öncelikle, yoksulluk nafakasının yoksulluğa düşen veya düşecek olan tarafça talep edilmesi gerekir (MK. md. 175/I). Hakim, boşanma sonucunda yoksulluğa düşmüş veya düşecek olan taraftan her hangi bir yoksulluk nafakası talebiyle karşılaşmadan, resen bu yönde her hangi bir

\footnotetext{
${ }^{52}$ Kemmler, Jutta Hahn, Das neue nacheheliche Unterhaltsrecht und seine Auswirkungen auf das Sozialrecht, Bochum 1979, sh. 7; Bozoval1, Halil, Türk Medeni Hukukunda Bakım Nafakası, İstanbul 1990, sh. 67; İnal, Nihat, AD., 1970, S. 6, sh. 383; Tulumlu, Mehmet Akif, Evliliğin Butlanı Boşanma, Ayrılık ve Boşanmanın Hukuki Sonuçları, Ankara 2002, sh. 459; Ruhi, Ahmet Cemal, Türk Hukukunda Nafaka ve Nafaka Alacaklarının Yabancı Ülkelerde tahsili, Ankara 2003, sh. 70; Hamzaçelebi, M., "Boşanma Öncesi ve Sonrası Nafaka", Yargitay Dergisi, C. 26., S. 3, 2000, sh. 360; Öztan, sh. 497.

${ }^{53}$ Kanun koyucu, Eski Medeni Kanun'da, kadının erkeğe yoksulluk nafakası ödemesi için kadının durumun refah halinde olması şartını aramıştır (EMK. md. 144/I).

${ }^{54}$ İnsan Hakları Evrensel Beyannamesi'nin özellikle 1, 2, 7 maddelerinde herkesin eşit ve hür doğduğu, kanun önünde eşit olduğu ve dolayısıyla da bireyler arasında cinsiyet vb. kıstaslara göre ayrım yapılamayacağı açıkça ifade edilmiştir.

551982 Tarihli Türkiye Cumhuriyeti Anayasası temel olarak kadın erkek eşitliği ilkesinden hareket etmiştir. Özellikle Anayasa'nın İkinci Kısmı'nda düzenlenmiş olan“Temel Hak ve Ödevler" bu temel ilke üzerinde şekillendirilmiştir.
} 
karar veremez ${ }^{56}$. Nitekim, Yargitay ve Federal Mahkeme'nin uygulaması da bu yöndedir ${ }^{57}$.

Ancak, Yargıtay, vermiş olduğu bazı kararlarında ${ }^{58}$, "davacı ev hanımıdır, bir işi yada yapabileceği bir mesleği yoktur" şeklindeki ifadelerin yoksulluk nafakası talebi olarak değerlendirilmesi yönünde karar vermiştir.

Anlaşmalı boşanmada boşanan tarafların, boşanmanın feri sonuçlarından olan yoksulluk nafakasına ilişkin olarak da bir anlaşmaya varmış olmaları gerekir. Zira, anlaşmalı boşanmada, tarafların boşanmanın mali sonuçlarına iliş̧in olarak anlaşmış olmaları, anlaşmalı boşanmanın maddi koşullarındandır ${ }^{59}$ Keza, boşanan tarafların bu konuda yapmış oldukları anlaşmalarının hakim tarafından onaylanması da yasal bir zorunluluktur (MK. md. 166/III).

II-Yoksulluk Nafakası Talebinde Bulunan Tarafın Kusuru Karşı Tarafın Kusurundan Daha Ağır Olmamalıdır.

Kanun koyucu, boşanma sonucunda yoksulluğa düşen veya düşecek olan tarafin yoksulluk nafakası talep edebilmesi için, ayrıca kendi kusurunun karşı tarafın kusurundan ağır olmaması koşulunu aramıştır (MK. md. 175/I). Dolayısıyla, boşanmaya sebebiyet veren olaylarda tamamen veya daha ağır kusurlu olan taraf, yoksulluk nafakası talep edemez ${ }^{60}$. Ancak, Yargitay, verdiği bazı kararlarında boşanan eşlerin her ikisinin eşit derecede kusurlu olmaları halinde, talep eden taraf lehine yoksulluk nafakasina hükmedileceğini öngörmüştür ${ }^{61}$.

Kanımızca, kanun koyucu, MK. md. $175^{\prime}$ in metnini pek isabetli kaleme almamıştır. Çünkü, MK. md. 175 ' in birinci ve ikinci fikrasının metni ilk bakışta birbiriyle çelişir nitelikte görünmektedir. Zira, Kanun koyucu, MK. md. 175/II' de "Nafaka yükümlüsünün kusuru aranmaz" derken, birinci fikrada, '’Boşanma yüzünden yoksulluğa düşecek taraf, kusuru daha ağır olmamak koşuluyla geçimi için diğer taraftan mali gücü oranında süresiz olarak nafaka isteyebilir" demektedir. Kanun koyucu, aslında bu düzenlemenin birinci fikrasında, kusuruyla boşanmaya sebebiyet veren tarafın yoksulluk nafakası talep edemeyeceğini, buna karşın ikinci fikrada ise, kusur sebebine dayanmayan boşanma sebebinde ${ }^{62}$ nafaka

\footnotetext{
${ }^{56}$ Öztan, sh. 497, 498; Ruhi, sh. 78.

${ }^{57}$ 2. HD., 01.04.2002,15276 E, 17072 K. (Özugur, sh. 1004); BGE. 130 III 537.

${ }^{58}$ 2. HD., 03.2.2003, 156E-1423 K. (Gençcan, sh. 967).

${ }^{59}$ Geniş bilgi için bkz., Özdemir, sh. 158 vd.

60 2. HD., 08.03.2002, 2266 E., 3207 K. (Özugur, sh. 1004); 2. HD., 15.02.2002, 2445 K., 2057 E. (Gençcan, sh. 963 ).

${ }^{61}$ 2. HD.,16.12.2002, 13071 E,13937 K. (Gençcan, sh. 964).

${ }^{62}$ Medeni Kanun'da kusura dayanmayan boşanma sebebi de öngörülmüştür. Eğer, eşlerden
} 
yükümlüsünün kusurunun aranmayacağını kast etmiştir. Kanımızca, kanun koyucu, yoksulluk nafakasına ilişkin düzenlemeyi yaparken, boşanan tarafların kusurlarıyla ilgilenmekten ziyade, boşanma sonucunda yoksulluğa düssen taraf, diğer taraftan mali gücü oranında ve hakkaniyete uygun bir nafaka talebinde bulunabilir şeklinde bir düzenleme yapması daha isabetli olurdu. Nitekim, İsviçre kanun koyucusu, yoksulluk nafakasına ilişkin düzenlemede tarafların kusuruna hiç değinmemiştir (ZGB. Art. 125/I) ${ }^{63}$.

\section{III-Yoksulluk Nafakası Talebinde Bulunan Tarafın Boşanma Yüzünden Yoksulluğa Düșmüș Olması Gerekir.}

Yoksulluk nafakası talep eden tarafın, bu yöndeki isteğinin mahkemece kabul edilebilmesi için, boşanmadan dolayı bu kişinin yoksulluğa düşmesi gerekir. Kanun koyucu, Yeni Medeni Kanun'da yoksulluk nafakasına hükmedilmesi için, boşanma sonucunda yoksulluğa düşmeyi yeterli görmüştür. Bunun yanında, ayrıca yoksulluğun büyük olması gibi ek koşullara gerek görmemiştir. Kanun koyucunun bu yöndeki tercihi, kanımızca, daha isabetlidir. Zira, boşanma neticesinde düşülen yoksulluğun derecesi, hükmedilecek nafakayla değil, aksine, hükmedilecek nafakanın miktarıyla ilgili olan bir sorundur.

Yoksulluğa düşmekten, boşanan taraflardan birisinin hiçbir gelire sahip olmamasını, işsiz olmasını, çalışamayacak durumda olmasını veya boşanma sonucunda işini kaybetmiş olması gibi halleri anlamak gerekir ${ }^{64}$. Boşanan eşin boşanmadan önceki refah seviyesinden daha düşük hayat yaşaması, yoksulluğa düşme olarak değerlendirilemez. Nitekim, Yargıtay, verdiği bazı kararlarda, SSK. ${ }^{65}$ veya BAĞ-KUR. ${ }^{66}$ aylığı olanları veyahut da asgari ücretle çalışanlari ${ }^{67}$, yoksulluğa düşmüş olarak kabul etmemektedir.

birisi, akıl hastasıysa ve bu yüzden ortak hayat diğer eş için çekilmez hale gelmişse, hastalığın geçmesine olanak bulunmadığı resmi sağlık kurulu raporuyla tespit edilmek koşuluyla, bu eş boșanma davası açabilir (MK. md. 165).

${ }^{63}$ İsviçre Medeni Kanunu'nun 125. maddesinin birinci fikrasına göre (ZGB. Art. 125/I),

"Boşanma sonucu yaşııık yardım sandığının ödemesi de dahil olarak geçimini uygun koşullarda sağlaması kendinden beklenmeyen eşe, diğeri hakkaniyete uygun bir katkıda bulunmak zorundadır'.

${ }^{64}$ Oguzman, Kemal/Dural, Mustafa, 1998 İstanbul, sh. 146; Nihat, İnal, Yoksulluk Nafakas1 ve Tazminat, AD. 1970, S. 5. sh. 374; Yüce, Turhan, Evlilik Hukukunda Nafaka, AD. 1951, S. 12, sh. 1830; Öztan, sh. 499.

${ }^{65}$ 2. HD., 25.12.2002, 13554 E., 14829 K., (Gençcan, sh. 964).

${ }^{66}$ 2. HD., 01.10.2002, 10258 E., 11123 K., (Gençcan, sh. 965).

${ }^{67}$ 2. HD., 05.03.2003. 1901 E, 2929 K., (Gençcan, sh .966). 


\section{IV-Yoksulluk Nafakası Miktarının Nafaka Yükümlüsünün Mali Gücüyle Orantılı Olmalıdır.}

Medeni kanuna göre hakim, yoksulluk nafakasının miktarı belirlerken, sadece, nafaka yükümlüsünün ödeme gücünü dikkate almaktadır (MK. md. 175/I) ${ }^{68}$ Kanımızca, bu düzenleme bazı yönlerden eksiktir. Zira, yoksulluk nafakasında sadece bir taraf değil, birden fazla yani iki taraf vardır. Dolayısıyla da, bu iki tarafın içinde bulunduğu ve kendilerine has bazı özel koşullar mevcuttur. İki tarafın içinde bulunduğu özel koşullardan sadece nafaka yükümlüsünün koşullarını dikkate alarak, yoksulluk nafakasının miktarını belirlemek, kanımızca, hakkaniyete ve menfaat içtihatçılığına uygun düşmez. Nitekim, bu düşünceden hareket eden İsviçre kanun kuyucusu, Türk kanun koyucundan farklı olarak, nafaka miktarını belirlerken, sadece bir taraftan bahsetmeyerek, her iki taraf için de dikkate alınması gereken unsurları veya koşulları yasal düzenlemede açıç̧a ifade etmiştir (ZGB. Art. 124/II) ${ }^{69}$.

Ancak, Türk kanun koyucusu, nafakanın ödenmesini düzenlediği Medeni Kanun'un 176. maddesinin dördüncü fikrasında "tarafların mali durumlarının değişmesi veya hakkaniyet gerektirdiği hallerde, iradın arttırılması veya eksiltilmesine karar verebilir" diyerek, irat şeklinde ödenen yoksulluk nafakasının miktarının sonradan belirlenmesinde, boşanan her iki tarafın da mali durumlarının dikkate alınmasının gerektiğine işaret etmiștir. Bu düzenleme de bize göstermektedir ki, mahkemeler, yoksulluk nafakasına hükmederken, her iki tarafın da durumlarını dikkate alarak yoksulluk nafakasının miktarını belirlemelidir ${ }^{70}$.

\section{7-YOKSULLUK NAFAKASINDA YETKİLİ VE GÖREVLI MAHKEME.}

Kanun koyucu, Medeni Kanun'da yoksulluk nafakasına hükmedecek yetkili mahkemeye ilişkin olarak her hangi genel bir yetki kuralının öngörmemiștir. Buna mukabil, kanun koyucu, boşanma kararının kesinleşmesinden sonra açılacak olan yoksulluk nafakası davaları için, özel bir düzenleme getirmiştir. Bu düzenlemeye göre, boşanmadan sonra açılacak yoksulluk nafakası davalarında, nafaka alacaklısının yerleşim yeri mahkemesi yetkilidir (MK. md. 177).

\footnotetext{
${ }^{68}$ Yargıtay, verdiği kararında çalışmayan ve akıl hastası olan kocayı, yoksulluk nafaka yükümlüsü olarak tutmamıştır. 2. HD. 1994, 872 E., 1778 K., (İnternet).

${ }_{69}$ İsviçre Medeni Kanunu'nun 125. maddesinin ikinci fikrasında (ZGB. Art. 125/II), boşanma sonucunda hakimin yoksulluk nafakasına hükmederken uyacağı bazı kıstaslar ön görmüştür. Bunlar; "1-Evlilikteki, görev dağılımı, 2-Evlilik süresi, 3-Evlilik sırasında eşlerin yaşam standardı, 4-Eşlerin yaş ve sağlık durumu., 5-Eşlerin gelir ve servet durumu, 6-Çocuklar için girilen yükümlülüklerin süresi ve durumu, 7-Mesleki formasyon ve kazanç beklentileri, ayrıca nafakadan yararlanacak tarafın mesleki geliri için yapılması zorunlu masraflardır."

${ }^{70}$ BGE. 127 III 136.
} 
Yoksulluk nafakası, genellikle, boşanma davasıyla beraber talep edildiği için, yoksulluk nafakasına bakacak olan görevli ve yetkili mahkeme de, boşanma davasına bakan görevli ve yetkili mahkemedir.

4787 Sayılı Aile Mahkemelerinin Kuruluş, Görev ve Yargilama Usullerine Dair Kanun'un 4. maddesinin birinci fikrasına göre, “22.11.2001 tarihli ve 4721 sayılı Türk Medeni Kanununun İkinci Kitabı ile 3.12.2001 tarihli ve 4722 sayılı Türk Medeni Kanununun Yürürlüğü ve Uygulama Şekli Hakkında Kanuna göre aile hukukundan doğan dava ve işler", Aile Mahkemeleri'nin görevindedir.

\section{8-YOKSULLUK NAFAKASININ TALEP EDİLME USULÜ.}

Uygulamada yoksulluk nafakası genellikle boşanma davasıyla beraber talep edilmektedir. Dolayısıyla, hakim, boşanmaya karar verdikten sonra, yoksulluk nafakasına ilişkin olan talebi de karara bağlamaktadır.

Öğretide ve uygulamada, önceleri, yoksulluk nafakasının talep edilmesi usulüne ilişsin olarak farklı görüşler mevcuttu ${ }^{71}$. Kanımızca, bu tartışmaların hepsi, Medeni Kanun'da yer alan yeni düzenlemeyle tamamen geride kalmıştır. Zira, kanun koyucu, MK. md. 177' de 'boşanmadan sonra açılacak nafaka davalarında, nafaka alacaklısının yerleşim yeri mahkemesi yetkilidir" diyerek, hem yoksulluk nafakasında yetkiye ilişkin bir hüküm getirmekte hem de boşanma kararı kesinleştikten sonra da yoksulluk nafakasının talep edilebileceğini açıkça ifade etmiş olmaktadır. Keza, kanun koyucu, MK. md. 178' de "evliliğin boşanma sebebiyle sona ermesinden doğan dava hakları, boşanma hükmünün kesinleşmesinin üzerinden bir yıl geçmekle zamanaşımına uğrar' demekle, boşanmanın mali sonucu olan yoksulluk nafakasın da boşanma davası kesinleştikten sonra bir yıl içinde talep edilebileceğini düzenlemiş olmaktadır.

Boşanan taraflar, yoksulluk nafakası miktarı üzerinde anlaşamamışlarsa, yoksulluk nafakasının miktarını hakim belirleyecektir (MK. md. 175). Eğer, taraflar, anlaşmalı olarak boşanıyorlarsa ve yoksulluk nafakası konusunda bir şekilde anlaşmışlarsa, tarafların bu anlaşmaları hakim tarafından onaylanması gerekir (MK. md. 166/III). Yargıtay, anlaşmalı boşanmada tarafların yoksulluk nafakasına ilişkin olarak her hangi bir talepte bulunmamasını, davacının o tarihte yoksulluğa düşmediği yönünde kesin hüküm oluşturduğu şeklinde kabul etmiştir ${ }^{72}$. Kanımızca, Yargıtay'ın bu yaklaşımı yerindedir ${ }^{73^{3}}$. Zira, tarafların anlaşmalı boşanmada

\footnotetext{
${ }^{71}$ Kuleli, Şakir, Nafaka Davaları, YD. S. 1, 2, sh. 115 vd.; 2. HD., 22.12.1975, 9323 E., 9539 K, YKD., 1975, C. II, sh. 953, 954.

72 2. HD. 7.3.1997, 1032/2584

73 Öztan, Yargıtay'ın bu konudaki görüşüne katılmamakta ve bu durumda boşanan eşelerden birisinin boşanma anında yoksulluğa düşmediği hususunda kesin bir karinenin olmadığını ileri sürmektedir. Kanımızca, burada tartışılması gereken husus kesin karine olup olmadığı değil,
} 
boşanmanın mali sonuçları üzerinde anlaşmaları, anlaşmalı boşanmanın maddi unsurlarındandır. Bu konuda tarafların her hangi bir anlaşmasının olmaması, anlaşmalı boşanmanın maddi unsurlarından birisinin gerçekleşmemesi anlamına gelir ki, bu taktirde, anlaşmalı boşanmadan bahsedilemez. Eğer, anlaşmalı boşanmanın metninde, yoksulluk nafakasına ilişkin olarak her hangi bir hüküm yoksa, bu durumda, boşanma sonucunda yoksulluğa düşen her hangi bir taraf da yok demektir. Ayrıca, taraflarca yapılan bu anlaşma, hakim onayından (MK. md. 166/III) ve netice itibariyle de Yargıtay denetiminden geçtiği için boşanan taraflar bakımından, hakimin yapmış olduğu işlemler, usul hukuku hükümleri gereğince de kesin hüküm teşkil eder.

Keza, boşanan taraflar, boşanma davası devam ederken de yoksulluk nafakası ve yoksulluk nafakasının miktarı hususunda her hangi bir anlaşmaya varabilirler. $\mathrm{Bu}$ durumda, taraflarca yapılan bu anlaşmanın MK. md. 184/V' göre hakim tarafindan onaylanması gerekir.

\section{9-YOKSULLUK NAFAKASININ SÜRESİ.}

Kanun koyucu, yoksulluk nafakasının süresiz (devamli) olarak ödeneceğini hükme bağlamıştır (MK. md. 175/I). Yoksulluk nafakasının süresiz ödenmesi, sadece, nafakanın irat şeklinde ödenmesi durumunda söz konusudur. Yoksa, tamamı bir defada ödenen yoksulluk nafakasının süresiz olarak ödenmesinden bahsedilmez. Ĕger, yoksulluk nafakası, belli bir süre için istenmiş ve mahkemenin bu yöndeki kararı da kesinleşmişse, yoksulluk nafakas1 alacaklısı, daha sonra bu sürenin uzatılması yönünde bir talepte bulunamaz. Zira, bu konuda taraflar açısından kesin hüküm söz konusudur ${ }^{74}$.

Yoksulluk nafakasının süresiz olarak ödenmesi demek, yoksulluk nafakasının her zaman ödeneceği anlamına gelmez. Yoksulluk nafakası, bazı durumlarda, kendiliğinden, bazı durumlarda da, mahkeme kararıyla ortadan kalkar. Yoksulluk nafakası, nafaka alacaklısının evlenmesi yada taraflardan birisinin ölümü halinde kendiliğinden; yoksulluk nafakası alacaklısının evlenmeden fiilen evli gibi yaşaması, yoksulluğun ortadan kalkması yada haysiyetsiz hayat sürmesi durumlarında da, mahkeme kararıyla ortadan kalkar (MK. md. 176/III).

Kanımızca, yoksulluk nafakasının yukarıda bahsedilen durumlar dışında, süresiz olarak ödenmesi de doğru değildir. Zira, insanların yapmış olduğu bir davranıştan dolayı, ömür boyu sorumlu tutulmaları, hem insaflı değil, hem de hakkaniyete aykırıdır. Ayrıca, zaman aşımı ve hak düşürücü süre kavramlarının kabul edildiği bir hukuk sisteminde, boşanmadan

usul hukuku hükümlerine göre, mahkemenin verdiği kararının boşanan taraflar bakımından kesin hüküm oluşturup oluşmadığıdır. Yargı denetiminden geçen ve yargılama yolları tamamlanmış her hukuksal karar taraflar açısından kesin hüküm niteliğindendir.

${ }^{74}$ 2. HD., 20.10.1995, 105569 E., $10750 \mathrm{~K}$. 
kaynaklanan bir nafaka alacağının varlığının belli koşullar altında, nafaka borçlusunun veya nafaka alacaklısının yaşamı boyunca, sanki mülkiyet hakkıymış gibi sürekli kılması da anlaşılır değildir. Keza, hiç kimse, kendi kişilik haklarını bile aşırı olarak sınırlandıramazken (MK. md. 24), boşanan taraflardan birisinin sırf boşanan diğer taraf yoksulluğa düştü diyerek, süresiz olarak nafaka yükümlüsü kılmak kanımızca, adalet duygusunu da zedelemektedir.

Ayrıca, boşanan eşlerin yaşamlarını yeniden düzenleyebilmeleri için birbirlerinden kısa sürede kopmaları genellikle daha faydalı olur. Ancak, yoksulluk nafakası, sürekli olarak irat şeklinde ödendiği müddetçe, boşanmış tarafların birbirleriyle olan ilişkilerin sürekli hale gelmesi kaçınılmazdır. Keza, yoksulluk nafakası yükümlüsü olan tarafın, muhtemelen, kanunda yoksulluk nafakasının kaldırılması için ön görülmüş olan koşulların mevcut olup olmadığını sürekli olarak araştırmak istemesi ve böylece de yoksulluk nafakası alacaklısının özel hayatına sürekli olarak müdahale edilme tehlikesinin varlığ 1 , her halde hukukun sebep olacağı bir sonuç olamaz.

Ayrıca, yoksulluk vakıasının sebebi, sadece, eşinden boşanan tarafın davranışı olamaz. Zira, yoksulluk vakıası aynı zamanda toplumsal da bir olgudur. Dolayısıyla, aynı zamanda toplumsal bir olgu olan yoksulluğun sorumluluğunu, sırf evlenip boşandığ 1 diye boşanan taraflardan birisine aleyhine ömür boyu yüklenmesi, kanımızca, hakkaniyete ve mantığa da uygun bir çözüm değildir. Keza, irat şeklinde ödenen yoksulluk nafakası, bunu alan tarafi iyi niyetli veya kötü niyetli olarak, tembelliğe de sevk edebilir. Nafaka alacaklısı, çalışma yerine sürekli ödenen yoksulluk nafakası geliriyle geçinmeyi ve buna kanaat etmeyi de tercih edebilir. Kanun koyucunun, bu durumlara ilişkin olarak her hangi bir düzenleme getirmemesi de, kanımızca, ayrı bir eksiklik olarak değerlendirilebilir. Nitekim, İsviçre kanun koyucusu, nafaka talep eden tarafın, kasıtlı olarak ihtiyaç içinde bulunma halini sürdürmesi durumunda, nafaka talebinin kısmen veya tamamen reddedileceğini hükme bağlamıştır (ZGB. Art. $125 /$ III,3)

\section{0-YOKSULLUK NAFAKASININ ÖDENME ŞEKLİ.}

Hakim, yoksulluk nafakasının toptan veya irat şeklinde ödenmesine karar verebilir (MK. md. 176/I). Kanun koyucu, burada, hakime geniş bir taktir yetkisi tanımıştır. Hakim, bu kararını verirken, tarafların ekonomik durumlarını, taleplerini, olayların cereyan şeklini ve bütün koşulları dikkate almalıdır. Hakim, sadece, boşanan tarafların talepleriyle bağlı değildir. Uygulamada, genellikle yoksulluk nafakasının irat şeklinde ödenmesine karar verilmektedir ${ }^{75}$.

\footnotetext{
${ }^{75}$ 2. HD., 9.12. 1992, 12034 E., 12459 K.
} 
Hakim, zaman içerisinde, tarafların mali durumlarının değişmesi veya hakkaniyet gerektirdiği durumlarda, irat şeklinde ödenen yoksulluk nafakasının artırılmasına veya azaltılmasına da karar verebilir (MK. md. 176/VI). Ancak, hakimin bu konuda bir karar verebilmesi için öncelikle, boşanan taraflardan birisinin bu konudaki talebini mahkemeye yönetmesi gerekir. $\mathrm{Bu}$ yönde her hangi bir talep olmadan hakimin bu konuda kendiliğinden her hangi bir karar vermesi mümkün değildir.

Keza, hakim, talep halinde, irat şeklinde ödenen yoksulluk nafakasının gelecek yıllarda tarafların ekonomik ve sosyal durumlarına göre, ne miktarda ödeneceğine de karar verebilir (MK. md. 176/V). Kanımızca, kanun koyucunun bu düzenlemesi yerinde olmuştur. Zira, zamanla gelişen olaylar, irat şeklinde ödenen yoksulluk nafakasının miktarının değiştirilmesini zorunlu kılabilir. Burada, hakimin kararı, irat şeklinde ödenen yoksulluk nafakası miktarının sadece artırılması yönünde değil, aynı zamanda, azaltılması yönünde de olabilir. Hakim, olayları değerlendirerek, bu konudaki kararını hakkaniyete uygun olarak verecektir. Kanımızca, kanun koyucunun ön gördüğü bu düzenleme, aynı zamanda, usul ekonomisi açısında da yerinde bir düzenlemedir.

\section{1-YOKSULLUK NAFAKASI MIKTARININ GELECEK YILLARA İLIŞKİN OLARAK UYARLANMASI.}

Kanun koyucu, MK. md. 176/V' de, Eski Medeni Kanun'dan farklı olarak, "Hakim, istem halinde, irat biçiminde ödenmesine karar verilen maddi tazminat veya nafakanın gelecek yıllarda tarafların sosyal ve ekonomik durumlarına göre ne miktarda ne miktarda ödeneceğini karara bağlayabilir"' diyerek, yeni bir düzenleme getirmiştir.

Bizim de katıldığımız görüşe göre ${ }^{76}$, kanun koyucunun bu düzenlemesi yoksulluk nafakası bakımından isabetli olmuştur. Zira, zaman içerisinde, yoksulluk nafakası borçlusunun ve yoksulluk nafakası alacaklısının sosyal ve ekonomik durumlarında meydana gelen gelişmelere paralel olarak, irat şeklinde ödenen yoksulluk nafakası miktarının ayarlanması zarureti doğabilir. Özellikle, enflasyonun yüksek olduğu dönemlerde bu düzenlemenin önemi bir kez daha anlaşılacaktır. Zira, enflasyon sonucunda paranın değerinin düşmesi, doğal olarak, irat şeklinde ödenen yoksulluk nafakası miktarının gerçek değerinin düşmesine sebep alacak ve bunun sonucunda da yoksulluk nafakası alacaklısı olan taraf, bundan doğal olarak zarar görecektir. Dolayısıyla, bu durumda, yoksulluk nafakası alacaklısı, yoksulluk nafakası miktarının artırılması amacıyla, s1k aralıklarla mahkemeye baş vurma zorunluluğu doğacaktır. Kanun koyucu, bu yeni düzenlemeyle, bu tür olumsuzlukların önünü kesmeyi amaçlamıştır.

\footnotetext{
${ }^{76}$ Geniş bilgi için bkz. Kilıçoğlu, sh. 23.
} 
Kanımızca, kanun maddesinin metninden, irat şeklinde ödenen yoksulluk nafakasının geleceğe ilişkin olarak hakim tarafindan ayarlanmasından, sadece yoksulluk nafakasını miktarının arttırılmasını anlamamak gerekir. Filhakika, kanun koyucu, kanun maddesinde yoksulluk nafakası miktarının gelecek yıllarda arttırılmasından değil, 'ne miktarda", ödeneceğinden bahsetmiştir. Dolayısıyla, hakim, gelecek yıllarda ödenecek yoksulluk nafakası miktarını belirlerken, her somut olay için tarafların sosyal ve ekonomik durumlarını dikkate alarak, yoksulluk nafakası miktarının artırılmasına veya azaltılmasına karar verebilir. Nitekim, İsviçre kanun koyucusu, nafakanın nafaka miktarının ileriye dönük olarak artırılabileceğini veya azaltılabileceği "mahkeme nafaka miktarını, hayat pahalılığına bağlı olarak kendiliğinden artırılmasına ve eksiltilmesine karar verebilir'" (ZGB. Art. 128), diyerek, bu konuya açıklık getirmiştir.

Türk kanun koyucu, yoksulluk nafakası miktarının gelecek yıllara ilişkin olarak ayarlanmasında, İsviçre kanun koyucusundan farklı olarak, tarafların sadece ekonomik durumlarını değil, aynı zamanda, sosyal statülerini de dikkate almıștır. Kanımızca, Türk kanun koyucusunun düzenlemesi bu yönüyle İsviçre'deki düzenlemeye nazaran daha da isabetli olmuştur. Zira, nafaka miktarının gelecek yıllara ilişkin olarak belirlenmesinde, sadece tarafların ekonomik durumlarının temel alınması, nafaka miktarının belirlenmesi için yeterince sağlıklı bir kıstas değildir. Filhakika, insanların ihtiyaçları ve sosyal yaşantıları, sadece ekonomik kriterlere göre değil, aynı zamanda, sosyal statülerine göre de şekillenir.

\section{2-YOKSULLUK NAFAKASI MİKTARININ HAKİM KARARIYLA DEĞIŞTİRILMESI.}

Hakim, Medeni Kanun'un 176. maddesinin dördüncü fikrası gereğince, yoksulluk nafakasının irat şeklinde ödenmesine karar verilmesi halinde, tarafların mali durumlarının değişmesi veya hakkaniyetin gerektirdiği hallerde, irat şeklinde ödenen nafaka miktarının arttırılması veya azaltılmasina karar verebilir. Kanun koyucunun bu düzenlemesi, hayatın gerçeklerine daha uygundur. Zaman içerisinde, yoksulluk nafakası yükümlüsünün veya nafaka borçlusunun mali durumlarında değişiklik olması olağandır. Ayrıca, sadece yoksulluk nafakası yükümlüsünün mali durumunda ortaya çıkan değişiklikler değil, aynı zamanda, hakkaniyet de yoksulluk nafakası miktarının artırılmasına ve eksiltilmesine sebebiyet verebilir.

Yoksulluk nafakası miktarının eksiltilmesi veya artırılmasını için, boşanan taraflardan birisinin bunu talep etmiş olması gerekir. Bu konuda her hangi bir talep olmadan, hakimin resen, yoksulluk nafakası miktarına ilişkin olarak her hangi bir karar vermesi mümkün değildir. Kanunda, boşanan tarafların, yoksulluk nafakası miktarının yeniden belirlenmesi hususunda 
mahkemeden bir talepte bulunmasına ilişkin olarak, her hangi bir süre öngörülmemiştir. Kanımızca, kanun koyucunun burada her hangi bir süre öngörmemesi yerinde bir düzenlemedir. Zira, yoksulluk nafakası, irat olarak, süresiz olarak ödendiğinden dolayı, boşanan tarafların her birisinin, mali durumlarında ortaya çıkan değişiklikleri veya hakkaniyetin gerekliliğini ileri sürerek, yoksulluk nafakası miktarının değişmesini mahkemeden her zaman talep edebileceklerdir. Burada, Medeni Kanun'un 178. maddesinde yer alan bir yıllık zaman aşımı süresi uygulanmaz ${ }^{77}$.

Kanun koyucu, boşanmadan sonra açılacak yoksulluk nafakası davalarında, yoksulluk nafaka alacaklısının yerleșim yeri mahkemesinin özel yetkili mahkeme olarak tayin etmiştir (MK. md. 177).

\section{3-YOKSULLUK NAFAKASINA FAİZ YÜRÜTÜLMESİ}

Yoksulluk nafakası miktarının belirlenmesi, esas itibariyle, hakimin taktir yetkisinde olduğundan ve dolayısıyla da yoksulluk nafakası miktarının dava tarihinde muayyen ve muaccel olması mümkün olmadığından dolayı, yoksulluk nafakasına faiz yürütülemez. Ancak, mahkeme, yoksulluk nafakasına hükmeder ve muaccel olmuş yoksulluk nafakasının ödenmesinde yoksulluk nafaka borçlusu her hangi bir şekilde temerrüde düşerse, bu taktirde, talep halinde yoksulluk nafakasina faiz ödenir ${ }^{78}$. Burada yürütülecek faiz miktarı, yasal faiz miktarıdır.

\section{4-YOKSULLUK NAFAKASINIINSONA ERMESİ.}

Kanun koyucu, yoksulluk nafakasının sona ermesinde fakrı hükümler öngörmüştür. Bazı durumlarda, yoksulluk nafakası kendiliğinden, her hangi bir talep veya mahkeme kararına ihtiyaç duyulmadan sona ererken, bazı durumlarda da, yoksulluk nafakanın sona ermesi için, bunun mahkemeden talep edilerek hakim tarafından karara bağlanması gerekir.

\section{I-Yoksulluk Nafakasının Kendiliğinden Sona Ermesi.}

Yukarda da ifade edildiği gibi, Medeni Kanun'un 176. maddesinin üçüncü fikrasına göre, nafaka alacaklısının yeniden evlenmesi yada taraflardan birisinin ölmesi halinde, yoksulluk nafakası kendiliğinden sona erer. $\mathrm{Bu}$ durumda, sağ kalan tarafin mahkemeden her hangi bir talepte bulunmasina gerek yoktur.

Kanun koyucu, İsviçre kanun koyucudan farklı olarak, boşanan eşlerin nafaka alacaklısının sonradan evlenmesi halinde de nafakanın ödeneceğine

\footnotetext{
${ }^{77}$ Kilıçoğlu, sh. 20.

${ }^{78}$ Özuğur, sh. 1015.
} 
ilişkin bir anlaşma yapmaları durumunu düzenlememiştir. İsviçre Medeni Kanunu'na göre, boşanan tarafların bu konuda da bir anlaşma yapmaları mümkündür (ZGB. Art. 130/II). Bu konuda Medeni Kanun'umuzda her hangi bir düzenleme olmamakla beraber, kanımızca, her hangi bir yasaklama da yoktur. Dolayısıyla, boşanan taraflar, bu konuda bir anlaşmaya varmışlarsa ve bu anlaşma da hakimin denetiminden geçmişse, bu taktirde, yoksulluk nafakası alacaklısı taraf, sonradan evlense de, yoksulluk nafakasını alamaya devam etmelidir. Ancak, evlenmeyle, nafaka alacaklısının yoksulluğu bir şekilde ortadan kalkmışsa, bu durumda, yoksulluk nafakası yükümlüsü olan tarafın mahkemeye baş vurarak yoksulluk nafakasının kaldırılmasını hakimden talep etmesi mümkündür.

\section{II-Yoksulluk Nafakasının Mahkeme Kararıyla Sona Ermesi.}

Ayrıca, kanun koyucu, Medeni Kanun'un 176. maddesinin üçüncü fikrasında, yoksulluk nafakası alacaklısının, evlenme olmaksızın, fiilen evliymiş gibi yaşaması, yoksulluğun ortadan kalkması yada haysiyetsiz hayat sürmesi halinde mahkeme kararıyla sona ereceğini düzenlemiştir. Kanun koyucu, yoksulluk nafakası alacaklısının evlenmeden evliymiş gibi yaşaması halini hakime haklı olarak tespit ettirmek istemiştir.

Eğer, boşanan taraflar, yoksulluk nafakası alacaklısının sonradan evlenmesi halinde de nafaka ödeneceği hususunda bir anlaşmaya varmışlar ve bu anlaşma da hakim tarafından onaylanmışsa, kanımızca, yoksulluk nafakası alacaklısı, evlenmeden evliymiş gibi yaşam sürse dahi, yoksulluk nafakasını karşı taratan alamaya devam etmelidir. Zira, kişinin boşandıktan sonra birisiyle evlenmeden beraber yaşaması, haysiyetsiz bir yaşama olarak nitelendirilemez. Ancak, yoksulluk nafakası alacaklısının mali durumu, evlenmeden beraber yaşam sürmesi neticesinde iyileşmişse veya diğer bir ifadeyle yoksulluğu bu beraber yaşamadan dolayı ortadan kalmışsa, bu durumda, yoksulluk nafakası borçlusunun mahkemeye baş vurarak yoksulluk nafakasının kaldırılmasını hakimden talep edebilmesi gerekir.

Yoksulluk nafakası alacaklısının yoksulluğunun her hangi bir şekilde ortadan kalması halinde doğal olarak yoksulluk nafakasına hükmedilme gerekçesi de ortadan kaldırmış olur. Dolayısıyla bu durumda, yoksulluk nafakasının hala ödenmesinin söz konusu olmaması gerekir. Kanun koyucu, yoksulluk nafakasını alacaklısının yoksulluğunun ortadan kalkıp kalkmadığının tespit edilmesini mahkemeye bırakarak doğru bir düzenleme getirmiştir.

Keza, kanun koyucu, yoksulluk nafakası alacaklısının haysiyetsiz hayat sürmesi halinde yoksulluk nafakasının sona ermesini düzenlemekle de, hem aile hukukunun mantığına uygun hareket etmiş, hem de yoksulluk nafakasına hükmedilmesindeki ahlaksal yaklaşımı korumak istemiştir. Ayrıca, kanun koyucunun yoksulluk nafakası alacaklısının haysiyetsiz hayat 
sürmesi halinin tespitini mahkemenin yetkisine bırakması isabetli bir yöntemdir. Zira, yoksulluk nafakası borçlusunun nafaka yükümlülüğünden kurtulmak için nafaka alacaklısı hakkında her zaman gerçek dışı iddialarda bulunma ihtimali vardır.

\section{5-YOKSULLUK NAFAKASINDA ZAMAN AŞIMI.}

Kanun koyucu, boşanma sonucunda ortaya çıkan maddi ve manevi tazminatta olduğu gibi, ayni şekilde boşanma sonucunda ön görülen yoksulluk nafakasına ilişkin olarak da, zaman aşımı süresi öngörmüştür. Eğer, boşanma sonucunda yoksulluğa düşen taraf, boşanma davasiyla beraber karşı taraftan yoksulluk nafakası talep etmemişse, bu durumda, boşanma neticesinde yoksulluğa düşen tarafa ancak boşanma kararı kesinleştikten sonra bir yıl zarfında karşı taraftan yoksulluk nafakası talebinde bulunabilir (MK. md. 178).

Yoksulluk nafakası, ilam ve ilam sayılan belgeler haricinde (İIK. md. 38) kararlaştırılmışsa, irat şeklinde ödenen yoksulluk nafakası her dönem için beş yıllık zaman aşımına tabi olacaktır (BK. md. 126/1). Eğer, yoksulluk nafakası ilama bağlı ise, her ay veya her dönem için ön görülen irat şeklindeki yoksulluk nafakası, on yıllık zaman aşımına tabi olacaktır.

\section{ÜCÜNCÜ BÖLÜM.}

\section{BOSANMANIN BOSANAN TARAFLARIN MIRASCILIK HAKLARINA VE ÖLÜME BAĞLI TASARRUFLARA OLAN ETKİsi.}

\section{6-GENEL OLARAK.}

Eşler, yasal olarak birbirlerinin mirasçısıdır (MK. md. 499). Eşlerin mirasçılık hakkı, evlenme sözleşmesinin en önemli mali sonuçlarından birisidir $^{79}$. Kanun koyucu, hukuk politikası gereği, evlenme sözleşmesiyle hayatını birleştiren eşlerin kanun gereği başka her hangi bir hukuksal işleme gerek kalmaksızın birbirlerinin mirasçıları olmalarını istemiştir. Dolayısıyla, eşler, evlenmeden önce kan hısımlığ dolayısıyla birbirlerinin yasal mirasçısı bile olsalar, evlenme sözleşmesiyle bu yasal mirasçıllk hakları sona erer ve onun yerine evlenmeden kaynaklanan yeni yasal mirasçılık hakları devreye girer.

Kanunun koyucu, yine bir hukuk politikası gereği olarak, eşlere evlenmeyle yasal olarak tanınan yasal mirasçılık haklarının eşlerin boşanması sonucunda kendiliğinden ortadan kalkacağını düzenlemiştir. Kanun koyucu, sadece bu düzenlemeyle de yetinmemiş, aynı zamanda,

\footnotetext{
${ }^{79}$ Öğretide, boşanmanın boşanan eşlerin mirasçılık haklarına olan etkisini, boşanmanın kişisel sonuçları arasında gören yazarlar da vardır., Akıntürk, sh. 291; Öztan, sh. 463.
} 
boşanan eşlerin boşanmadan önce bir birleri lehine yapmış oldukları ölüme bağlı tasarrufların da aksi ölüme bağlı tasarruftan anlaşılamadığı taktirde, boşanma sonucunda kendiliğinden geçersiz hale geleceğini düzenlemiştir (MK. md. 181/I).

Kanun koyucu, MK. md. 181/II' de, Eski Medeni Kanun'da olmayan tamamen yeni bir düzenlemeye gitmiştir. Bu düzenlemeye göre, boşanma davası devam ederken ölen davacının mirasçılarının birisi, davaya devam etmesi ve davalı tarafin da kusurunu ispatlaması halinde, yukarı ifade edilen fikra hükmünün uygulanacağını öngörmüştür.

\section{7-BOŞANMANIN BOŞANAN TARAFLARIN MİRASÇILIK HAKLARINA OLAN ETKİSí.}

Evlilik sözleşmesini kurulması, nasıl eşlerin birbirlerine yasal olarak mirasçı olmalarını sağlıyorsa, evlilik sözleşmesinin boşanmayla sona ermesi de, aynı şekilde eşlerin birbirlerine olan yasal mirasçılık haklarının kendiliğinden sona ermesi sonucunu doğurur (MK. md. 181/I). Eğer, eşler, evlenmeden önce birbirlerine kan hısımlığı dolayısıyla mirasçı iseler, boşanmadan sonra da birbirlerine kan hısımlığından dolayı yasal mirasçı olmaya devam ederler ${ }^{80}$. Diğer bir ifadeyle, boşanan taraflar, boşanmayla evlilik sözleşmesinden kaynaklanan yasal mirasçılık sıfatlarını kendiliğinden kaybetmekteler, buna karşın, evlenme sözleşmesinin kurulması sonucunda ortadan kalkmış olan kan hısımlığından kaynaklanan yasal mirasçılık haklarını da yeniden geri kazanmaktadırlar.

Kanun koyucu, Medeni Kanun'da boşanan tarafların boşanma neticesinde mirasçılık sıfatlarını kaybetmeleri için mahkemenin vermiş olduğu boşanma kararının kesinleşip veya kesinleşmemiş olmasından bahsetmemiştir. Ancak, bu husus, mevcut hukuk düzeninde bir eksiklik olarak değerlendirilemez. Zira, boşanma kararının kesinleşmesi, kural olarak, usul hukukunu da ilgilendiren bir konudur. Dolayısıyla, boşanan eşlerin birbirlerine olan yasal mirasçılık haklarının ortadan kalkması için, Medeni Kanun'da aksine bir hüküm olmadığına göre, ilk dereceli mahkemenin vermiş olduğu boşanma kararının usul hukuku hükümlerine göre kesinleşmiş olması zorunludur. Filhakika, hukuk sistemimize göre, yargılama yolları da yargılama sürecinin bir parçasıdır ${ }^{81}$. Keza, MK. md. 181/II' in ifadesi de bu fikri destekler mahiyettedir.

\footnotetext{
${ }^{80}$ Lüchinger/Geiser, Art. 155, N. 3; Dural/Öz, sh. 43, 44; Akıntürk, sh. 291; Öztan, sh. 463.

${ }^{81}$ Mahkeme kararlarının kesinleşmesi hakkında geniş bilgi için bkz.; Kuru, Baki/Arslan, Ramazan/Yılmaz, Ejder, Genişletilmiş 15. Bası, Ankara 2004, sh. 723 vd.
} 


\section{8-BOSANMA DAVASI DEVAM EDERKEN ÖLEN DAVACININ MIRASÇILARINDAN BİRISININ SAĞ KALAN TARAFIN MIRASÇILIĞINI ENGELLEMESİ.}

\section{I-Genel Olarak.}

Kanun koyucu, İsviçre Medeni Kanunu'nda olmayan, tamamen yeni bir düzenlemeyi Türk Medeni Kanunu'nda öngörerek, boşanma davası devam ederken ölen davacının mirasçılarından birisinin davaya devem etmesi ve davalının da kusurlu olduğunu ispatlaması koşuluyla, sağ kalan eşin mirasçılık sıfatını kaybedeceğini düzenlemiştir (MK. md. 181/II).

Kanun koyucu, yapmış olduğu bu düzenlemeyle, boşanmada kusurlu olan davalı tarafın mirasçılarını korumayı değil, kusursuz olan davacı tarafın mirasçılarını korumayı tercih etmiştir. Ayrıca, kanun koyucu bu düzenlemeyi yaparken, aynı zaman boşanma talebinde bulunan davacı tarafın mutlaka boşanma davasını sonuçlandıracağı varsayımından da hareket etmiştir.

\section{II-Koșulları.}

Kanun koyucu, boşanma davası devam ederken ölen davacı eşin yerine onun mirasçılardan birisinin boşanma davasını davalı taraf aleyhine davam ettirerek, sağ kalan davalı eşin mirasçılık sıfatının ortadan kaldırılmasında bazı özel koşullar öngörmüştür. Bu koşullardan her hangisinin birisinin eksikliğinde sağ kalan davalı eşin mirasçılık sıfatı devam eder.

\section{A-Boșanma Davası Açılmış Olmalıdır.}

Ölmüş davacı tarafın mirasçılardan birisinin kusurlu ve sağ kalan tarafın mirasçılık hakkını ortadan kaldırılabilmesi için öncelikle, usulüne uygun olarak yetkili mahkemede bir boşanma davasının açılmış olması zorunludur. Zira, boşanma davası açılmamışsa, ölen eşin mirasçılarının bizzat boşanma davası açarak, sağ kalan eşin mirasçılık hakkını engellemeli hukuken mümkün değildir. Zira, boşanma davası açmak, kişiye sıkı sıkıya bağlı olan haklardandir ${ }^{82}$.

\section{B-Boşanma Davası Devam Ederken Davacı Taraf ÖImüş Olmalıdır.}

Eşlerden birisinin ölümü, her hangi hukuksal bir işleme gerek kalmadan evlilik sözleşmesini kendiliğinden sona erdirir. ${ }^{83}$. Eğer, eşlerden birisi boșanma davası açmıș ve bu boșanma davası devam ederken ölmüșse, bu taktirde boşanma davası hukuksal bir işleme gerek kalmadan kendiliğinden

${ }^{82}$ Geniş bilgi için bkz.; Öztan, sh. 436; Akıntürk, sh. 275; Köprülü/Kaneti, sh. 181.

${ }^{83}$ Akıntürk, sh.191,192; Öztan sh. 319. 
düşer. Dolayısıyla, bu halde, boşanma davasına ilişkin olarak kesinleşmiş bir mahkeme kararı da olamayacağı için sağ kalan eş, kanun gereği ölmüş olan davacı eşin yasal veya duruma göre iradi mirasçısı olmaya devam edecektir ${ }^{84}$.

Kanun koyucu, Yeni Medeni Kanun'da sağ kalan kusurlu davalı eşin mirasçı olmaması için, ölen davacı eşin mirasçılarına bir hak tanımıştır. Ancak, kanun koyucu, bu imkanı davalı eşin ölmesi durumunda ölen davalı eşin mirasçılarına tanımamıştır. Kanımızca, kanun koyucunun tek taraflı bu yaklaşımı doğru değildir. Eğer, kanun koyucu bu hakkı, ölen her iki tarafın da mirasçılarına tanısaydı, daha doğru ve adaletli bir düzenleme getirmiş olurdu ${ }^{85}$.

Nitekim, Alman kanun koyucusu, boşanma davası açmış eşlerin birlerinin mirasçı olmaları sorunu daha farklı ve dengeli bir şekilde çözmüştür. BGB § 1933' e göre, eğer, boşanmanın şartları gerçekleşmiş ve boşanma davası da açılmışsa, eşler, $\S \S 1569$ ile 1586 arasında düzenlenmiş nafaka alacakları saklı kalmak koşuluyla, birbirleri olan yasal mirasçılık haklarını kaybederler ${ }^{86}$. Bu düzenlemede Alman kanun koyucusu, boşanma koşullarının varlığında eşlerden birisi boşanma davası açmışsa, artık eşlerin mutlaka boşanacağ1 varsayımından hareket etmiş ve böylece de boşanma davası açmış eşlerin birbirlerinin yasal mirasçısı olamayacağını öngörmüştür.

\section{C-Ölen Davacı Tarafın Mirasçılardan Birisi Boşanma Davasına Devam Etmelidir.}

Sağ kalan davalı eşin mirasçılık hakkının elinden alınabilmesi için, ölen eşin mirasçılarından birisinin davaya devam ederek, sağ kalan davalı tarafın boşanmada kusurlu olduğunu mahkemeye ispat etmesi zorunludur. Kanun koyucu, maddede sadece ölen tarafın mirasçılarından birisi şeklinde söz etmekledir. Dolayısıyla, ölen davacının mirasçılarının sayısının bir den fazla olması durumunda, boşanma davasına bütün mirasçılarının devam etmesine gerek yoktur. Ancak, birden fazla mirasçının veya mirasçıların tamamın boşanma davasına devam etmesinde de her hangi yasal bir engel yoktur.

\footnotetext{
${ }^{84}$ Öztan, sh. 463; Akıntürk, sh. 291.

${ }^{85}$ Aynı fikirde bkz., Öztan, sh. 643; Ancak, öğretide, ölen kusursuz davalının mirasçıların da boşanma davasına devam edebileceğini savunan yazarlar vardır. Kanımızca, olması gereken hukuk açısından bu tür bir uygulama yerinde olmasına rağmen, pozitif hukuk anlayışı bakımından mümkün değildir. Zira, kanun koyucu, bu hakkı münhasıran davacı tarafın mirasçılarına tanımıştır. Aksi bir uygulama, kanun maddesinin kapsamını kanun koyucunun iradesine aykırı olarak genişletmek olur. Bkz., Atlaş, Hüseyin, Yabancı ve Türk Mahkeme Kararlarının Mirasçılığa Etkisi (MK. md. 181), (Prof. Dr. Turgut Kalpsüz’e Armağan, Ankara 2003), sh. 659-660.

${ }^{86}$ Geniş bilgi için bkz., Münchener Kommentar Bürgerliches Gesetzbuch Erbrecht, 4. Auflage, München 2004, Leipold, Dieter, sh. 123 vd.
} 
Ayrıca, kanun koyucu, Medeni Kanun'da ölen eşin mirasçılarının yasal veya iradi mirasçı veyahut da kaçıncı dereceden mirasçı oldukları hususlarını da düzenlememiştir. Kanımızca, mirasçıların yasal veya iradi mirasçı olmaları veyahut da kaçıncı dereceden mirasçı olduklarının da her hangi bir önemi yoktur. Mirasçılar, ister yasal, isterse iradi mirasçı olsun, kanun maddesinde yer alan koşullar mevcutsa, açılmış boşanma davasına devam ederek, kusurlu sağ kalan davalı tarafın mirasçılık sıfatının ortadan kalkmasinı mahkemeden talep edebilirler.

\section{Gerekir.}

D-Sağ Kalan Davalı Tarafın Kusurlu Olduğunun İspat Edilmesi

Boşanma davasında davacı tarafin ölümü halinde, mirasçılardan birisinin boşanma davasına devam ederek, sağ kalan davalı tarafın mirasçılık sıfatını ortadan kaldırabilmesi için, davacının mirasçının sağ kalan davalı eşin kusurluluğunu ayrıca ispat etmesi gerekir. Kanun koyucu, davalı tarafin kusurunun ispatını, boşanma davasına devem eden mirasçıya yüklemiştir. Kanun koyucunun bu düzenlemesi, hem genel ispat hukukuna uygun hem de işin niteliğine uygundur. Zira, iddiasını iddia eden ispat eder (MK. md. 6).

Kanun koyucu, kanun maddesinde, sadece kusurdan bahsetmiştir. Oysa, kusurun niteliğinden hiç bir şekilde bahsetmemiştir. Öğretide bazı yazarlar, kusur kavramından davalı eşin kusurunun ağır olmasını anlamaktadırlar ${ }^{87}$. Biz, bu görüsse katılmıyoruz. Zira, kanun koyucu, yasal düzenlemede davalı eşin kusuru açısından bir her hangi ayrıma gitmemiștir. Kanımızca, burada kanun koyucunun aradığı kusur, ağır kusur değil, boşanma davasının dayandığ 1 ve boşanmaya sebebiyet verecek yoğunlukta olan kusurdur ${ }^{88}$. Zira, kanun koyucunun bu düzenlemeyi yapmaktan amac1, nasıl olsa boşanmaya sebebiyet veren tarafın kusurlu davranışının bu evliliği sona erdireceği varsayımıdır. Eğer, davalı tarafın kusurlu davranışı, hakimin boşanma kararı vermesi için yeterli olacaksa, doğal olarak, evlilik birliği de sona erecektir. Öyle ise, bu taktirde, boşanan tarafların birbirlerine mirasçı olmaları da mümkün değildir.

\section{9-BOŞANMANIN ÖLÜME BAĞLI TASARRUFLARA OLAN ETKİSİ.}

\section{I-Genel Olarak.}

Pek tabidir ki, eşlerin birbirleri lehine yapmış oldukları ölüme bağlı tasarruflar, tarafların beklemece ekonomik haklarının en önemli kısmını oluşturur. Evlenmeyle hayatlarını birleştiren eşlerin, çeşitli sebeplerden

\footnotetext{
${ }^{87}$ Akıntürk, sh. 291.

${ }^{88}$ Benzer görüş, sayın Öztan tarafından dolaylı olarak ifade edilmektedir; Bkz., Öztan, sh. 463.
} 
dolayı, birbirleri lehine ölüme bağlı tasarruflarda bulunmaları doğaldır. Zira, evlenen eşler, genellikle, bu evlilik birliğinin ölüme kadar devam edeceğini düşünürler ve bundan dolayı da birbirleri lehine ölüme bağlı tasarruflarda bulunabilirler ${ }^{89}$. Ancak, evlilik birliğinin boşanma sonucunda sona ermesi durumunda, doğal olarak, söz konusu ölüme bağlı tasarrufların yapılma sebepleri de büyük ölçüde genellikle kendiliğinden ortadan kalmış olur. Pek tabidir ki, boşanma sonucunda tarafların yasal mirasçılık hakları nasıl ortadan kaldırıyorsa, tarafların birbirleri lehine yapmış oldukları ölüme bağlı tasarruflar da ortadan kalkar.

\section{II-Boşanmanın Ölüme Bağlı Tasarruflara Olan Etkisinin Koşulları}

Mahkemenin vermiş olduğu boşanma kararının kesinleşmesiyle, boşanan tarafların birbirleri lehine yapmış oldukları ölüme bağlı tasarruflar da kanunda ön görülen bazı koşulların mevcudiyetinde, kural olarak, hiçbir başka hukuksal işleme gerek kalmadan, kendiliğinden sona erer. Eğer, söz konusu bu koşullardan her hangi birisi yoksa, bu durumda, boşanma ölüme bağlı tasarrufların sona ermesi neticesini doğurmaz.

\section{A-Geçerli Ölüme Bağlı Bir Tasarruf Olmalıdır.}

Boşanan tarafların bir birleri lehine yapmış oldukları ölüme bağlı bir tasarrufun kendiliğinden sona ermesi için, öncelikle, boşanan eşler tarafından yapılmış, geçerli ölüme bağlı bir tasarrufun olması gerekir. Söz konusu ölüme bağlı tasarruf, şekli anlamda ölüme bağlı tasarruflardan, vasiyetname veya miras sözleşmesi şeklinde olabilir. Boşanan taraflar, yapmış oldukları bu şekli anlamda ölüme bağlı tasarruflarla, birbirlerini vasiyet alacaklısı veya iradi mirasçı olarak da tayin etmiş olabilirler.

\section{B-Ölüme Bağlı Tasarrufun Muhtevasından Aksi Anlaşılmamalıdır.}

Ayrıca, ölüme bağlı tasarrufların boşanma sonucunda kendiliğinden sona ermemesi için, ölüme bağlı tasarrufun muhtevasından aksi yönde bir anlamın çıkartılmaması gerekir. Kanun koyucu, bu düzenlemeyle, boşanan eşlerin iradelerine önem vererek, onların isterlerse şekli anlamda ölüme bağlı tasarruflar vasıtasıyla boşanmaya rağmen birbirlerinin iradi mirasçısı veya vasiyet alacaklısı olmalarını kabul etmiştir. Tarafların bu konudaki iradeleri, ölüme bağlı tasarruflarda açıkça yer alacağı gibi, aynı zamanda, ölüme bağlı tasarrufların yorumlanmasiyla da tespit edilebilir. Burada uygulanacak yorum kuralları, miras hukukunda ölüme bağlı tasarrufların yorumlanmasinda uyulan yorum kuralları olmalıdır ${ }^{90}$.

${ }^{89}$ Dural, Mustafa, Miras Sözleşmeleri, İstanbul 1980, sh. 209; Mustafa, Dural/Turgut Öz, Türk Özel Hukuku, Cilt IV., Miras Hukuku, Yenilenmiş 2. Bası, İstanbul 2003. sh. 132.

${ }^{90}$ Ölüme bağlı tasarrufların yorumlanmasında bazı özel yorum kurallar geçerlidir. Geniş bilgi 


\section{C-Boșanmanın Kesinleșmiş Olması Gerekir.}

Ölüme bağlı tasarrufların, boşanma sonucunda kendiliğinde sona ermesi için, mahkemenin verdiği boşanma kararının kesinleşmiş olması gerekir. Boşanma kararı kesinleşinceye kadar, hukuken evlilik sözleşmesi geçerli demektir ve eşler de, hale ölüme bağlı tasarruflar sayesinde birbirinin müstakbel iradi mirasçıları veya vasiyet alacaklısıdırlar. Ancak, aşağıda da inceleneceği gibi, bazı koşullar altında, mirasçılardan birisinin boşanma davası kesinleşmeden eşlerden birisi ölmesi halinde, kusurlu davalı eş lehine yapılan ölüme bağlı tasarrufların geçersiz sayılmasını talep edebilir.

\section{0-BOSANMA DAVASI DEVAM EDERKEN ÖLEN DAVACI TARAFIN YERINE MIRASÇILARINDAN BÍRISIN DAVAYA DEVAM EDEREK DAVALI TARAF LERINE YAPILAN ÖLÜME BAĞLI TASARRUFLARI GEÇERSİZ KILMASI.}

\section{I-Genel Olarak.}

Kanun koyucu, MK. md.181/II de, "Boşanma davası devam ederken, ölen davacının mirasçılarından birisinin davaya devam etmesi ve davalının kusurunun ispatlanması halinde de yukarıdaki fıkra hükmü uygulanır' diyerek, boşanma davası devam ederken, ölen davacı tarafın mirasçılardan birisinin, boșanma davasına devam edip, davalı tarafın kusurlu olduğunu ispatlayarak, davalı taraf lehine yapılmış ölüme bağlı tasarrufları da geçersiz kılabileceği düzenlemiştir.

\section{II-Koșulları.}

Boşanma davası devam ederken, davacı tarafın ölmesi halinde, davacı tarafin mirasçılardan birisinin veya tamamının, boşanma davasına devam ederek, kusurlu davalı eş lehine yapılmış olan ölüme bağlı tasarrufları geçersiz kılabilmesi için, kanun kuyucu bazı koşullar öngörmüştür. $\mathrm{Bu}$ koşullardan bir veya bir kaçının mevcut olmaması halinde, kusurlu davalı eş lehine yapılmış ölüme bağlı tasarrufların mahkeme kararıyla geçersiz hale getirilmesi söz konusu olamaz.

\section{A-Boşanma Davasının Açıımış Olması Gerekir.}

Boşanma halinde, ölen davacı eşin mirasçılardan birisinin davaya devem ederek, kusurlu davalı eş lehine yapmış ölüme bağlı tasarrufları geçersiz kılması için, ölen davacı tarafa boșanma davasının açılmıș olması zorunludur. Eğer boşanma davası açılmamışsa, eşler boşanmayı düşünüyor

için bkz.; İnan, Ali Naim/Ertaş, Şeref/Ablaş, Hakan, Türk Medeni Hukuku, Miras Hukuku, 5. Bas1, 2004 Ankara, sh. 269 vd.; Dural/Öz, sh .211 vd. 
olsalar bile, eşlerden birisinin ölümü sonucunda, onların bir birleri lehine yapmış oldukları ölüme bağlı tasarrufları geçersiz kılmak için, tarafların mirasçılarının mahkemeye baş vurmaları mümkün değildir. Ancak, eşlerin birbirleri lehine yaptıkları ölüme bağlı tasarruflara karşı, mirasçılar, miras hukukundan kaynaklanan başka hukuki sebeplere istinaden, ölüme bağlı tasarrufların iptalini veya tenkis edilmesini mahkemeden talep edebilirler.

\section{B-Boşanma Davası Devam Ederken Davacı Taraf Ölmüş Olmalıdır.}

Boşanma davası açmış olan davacı tarafın boşanma davası devam ederken ölmesi, ölen davacı tarafın mirasçılarının, boşanma davasına devam ederek, kusurlu davalı taraf lehine yapılmış ölüme bağlı tasarrufları iptal edilmesi hakkını doğurur. Boşanma davası devem ederken, davacı taraf ölmezse, pek tabidir ki, davacı tarafın mirasçılarının böyle bir hakları da olamaz. Keza, ölen davacı tarafın mirasçıları, boşanma davası devem ederken, ölen davacı tarafın açmış olduğu boşanma sebepleriyle de bağlıdır. Aksi düşünce, davanın dayandığı iddia ve sebeplerin sonradan değiştirilmesi ve genişletilmesi yasağının ihlali anlamına gelir ki, bu durum usul hukuku bakımından kabulü mümkün değildir ${ }^{91}$.

\section{C-Ölen Davacı Tarafın Mirasçılarından Birisi Boşanma Davasına Devam Etmelidir.}

Sağ kalan kusurlu davalı taraf lehine yapılmış ölüme bağlı tasarrufların ölen davacı tarafın mirasçılarının birisi tarafından iptal ettirilebilmesi için, boşanma davasına mirasçılardan birisi tarafindan devam edilmesi gerekir. Kanunu koyucu, sağ kalan davalı taraf lehine yapılmış ölüme bağlı tasarrufların iptal edilmesi için, boşanma davasına mirasçılardan bir tanesinin devam etmesini yeterli bulmuştur. Ayrıca, bu mirasçıların, yasal veya iradi mirasçı olmasının da her hangi bir önemi yoktur.

\section{D-Sağ Kalan Davalı Tarafın Kusurlu Olduğu İspat Edilmelidir.}

Davacı ölen tarafin mirasçılarının, açılmış boşanma davasına devam ederek, davalı taraf lehine yapılmış ölüme bağlı tasarrufları geçersiz kılabilmesi için, davacı tarafın mirasçı veya mirasçılarının, davalı tarafın kusurlu olduğunu ispat etmeleri gerekir. Kanımızca, davalı tarafın buradaki kusurunun özel bir ağırlı̆̆ 1 aranmaz. Burada aranan, daha önce de ifade edildiği gibi, boşanma davası açan tarafın, iddia ettiği boşanma sebeplerinde, davalı tarafin boşanmaya sebebiyet verecek derece kusurlu olmasıdır.

\footnotetext{
${ }^{91}$ Geniş bilgi için bkz.; Kuru/Arslan/Yılmaz, sh. 364 vd.
} 


\section{E-Ölüme Bağlı Tasarrufun Muhtevasından Aksi Anlaşılmamalıdır.}

Kanun koyucu, MK. md. 181/I' de, boşanmada, boşanan tarafların bir birleri lehine yapmıș oldukları ölüme bağlı tasarrufları, aksi ölüme bağlı tasarruftan anlaşı1madıkça kaybetmeyeceklerini düzenlemiștir. Dolayısıyla, boşanma davası açmış davacı tarafin ölmesi durumunda da, mirasçılardan birisinin boşanma davasına devam ederek, kusurlu davalı tarafin ölüme bağlı tasarrufla kazanmış olduğu hakkını kaybettirmesi, ölüme bağlı tasarrufun muhtevasından aksinin anlaşılmamasına bağlıdır. Yani, ölüme bağlı tasarrufta bulunan davacı taraf, yapmış olduğu ölüme bağlı tasarrufla, her halükarda, davalı tarafı iradi mirasçı veya vasiyet alacaklı olarak öngörmüşse, bu taktirde, ölen davacı tarafın mirasçılarından birisi veya tamamı, ölen davacı tarafin yerine boşanma davasına devam ederek, kusurlu davalı tarafın lehine yapılan ölüme bağlı tasarrufu iptal ettiremez.

\section{SONUÇ}

Evlilik sözleşmesinin doğası ve hukuksal niteliği gereği evlenen eşler, evlilik sözleşmesinin kurulmasıyla tamamen farklı ve yeni hukuksal bir statüye tabi olmaktadırlar. Eșlerin tabi olduğu bu farklı ve yeni hukuksal statü, evlilik sözleşmesinin sona ermesine kadar kural olarak devam eder. Evlilik sözleşmesi, ölüm gibi tabi olaylar neticesinde sona erebileceği gibi, aynı zamanda boşanmayla da sona erebilir.

Boşanma, boşanan taraflar bakımından bazı yeni önemli hukuksal sonuçlar getirir. Bu önemli hukuksal sonuçların başında, şüphesiz, incelemiş olduğumuz konu olan boşanmanın mali sonuçları yer alır. Doğal olarak, kanun yapma tekniği bakımından boşanma neticesinde boşanan tarafların yeniden oluşacak olan ekonomik durumlarını düzenlemek, kanun koyucu açısından kaçınılmaz bir durumdur. Zira, bu zorunluluğunun temelinde, hem işin mahiyeti hem de tarafların yeni hukuksal statüleri yatar.

Boşanmanın mali sonuçlarının en önemlilerinden birisi, şüphesiz, boşanmada boşanan taraflardan birisinin uğramış olduğu maddi veya manevi zararlarının tazmin edilmesi gelir. Ancak, boşanan tarafların uğramıș oldukları bu maddi veya manevi zararların tazmin edilebilmesinin bizim de katıldığımız görüşe göre, Medeni Kanun'da özel olarak düzenlenmesine gerek yoktur. Nitekim, İsviçre kanun koyucusu, aynı düşünceden hareketle, boşanmada maddi ve manevi tazminatın genel hükümlere göre çözülmesini tercih etmiş ve dolayısıyla da İsviçre Medeni Kanunu'nda önceden yer alan özel hükümleri kaldırmıştır. Kanımızca, olması gereken hukuk bakımından boşanmada maddi ve manevi zararların da tazmin edilmesi genel hükümlere göre çözümlenirse daha isabetli olacaktır.

Ayrıca, kanun koyucunun, maddi tazminatın irat olarak ödenmesiyle yoksulluk nafakasının irat olarak ödenmesini aynı yasal kurallara tabi tutması da, kanımızca, doğru bir yaklaşım olarak değerlendirilemez. Zira, 
boşanmada yoksulluk nafakasının öngörülme sebepleriyle, maddi tazminatın öngörülme sebepleri daha önce de ayrıntılı olarak açıklandığı gibi, birbirinden tamamen farklıdır. Dolayısıyla, bu düzenlemelerin olması gereken hukuk açısından da, bir an önce değiştirilmesi, kanımızca, daha isabetli olacaktır. Keza, mevcut düzenleme değiștirilirken, aynı zamanda maddi tazminatın irat olarak ödenmesi yerine, maddi veya manevi tazminat miktarlarının belli vadelere bağlanarak, yasal faiziyle birlikte ödenmesi imkan tanınması, ihtiyaçlara cevap veren bir düzenleme olarak ele alınmalidır.

Kanımızca, yoksulluk nafakasının kanunda öngörülen sebeplerden her hangi birisinin olmaması durumunda süresiz olarak ödenmesinin kabulü, hem hakkaniyete hem de mantık kurallarına aykırıdır. Zira, aynı zamanda toplumsal bir olgu olan yoksulluğun oluşturduğu ihtiyaçların veya sorunların giderilmesini veya hafifletilmesini, boşanan taraflardan sadece birisine yüklemek, pek doğru bir çözüm olmasa gerektir. Ayrıca, bu tür bir düzenlemeler, yoksulluk nafakası alacaklısını tembelliğe de sevk edebilir. Dolayısıyla, kanun koyucunun en azından bu konuya ilişkin olarak Medeni Kanun'da olması gereken hukuk açısından bazı düzenlemeler yapması yerinde olacaktır.

Medeni Kanun'un getirmiş olduğu yeniliklerden birisi de, ölen davacı tarafin mirasçılardan birisinin, boşanma davasına devam ederek, sağ kalan kusurlu davalı eşin mirasçılığını veya ölen tarafın sağ kalan davalı taraf lehine yapmış olduğu ölüme bağlı tasarrufları iptal ettirebilmesidir. Kanımızca, bu hüküm de, bazı yönlerden eksik olarak düzenlenmiştir. Bu eksikliklere örnek olarak, özellikle, ölen davacının mirasçılarının hangi süre zarfında davaya devam edecekleri veya mirasçıların boşanma davasından ve davacı eşin ölümünden nasıl haberdar edileceği gösterilebilir. Dolayısıyla, kanun koyucunun olması gereken hukuk açısından bu eksiklikleri de giderici bazı düzenlemelere gitmesi doğru olurdu. Zira, ölen eşin mirasçılarının açılmış boşanma davasından haberdar olmamaları genellikle muhtemeldir. Boşanma davasının müracaata kalması ve bu durumda da yasal sürelerin kısa olması ve sonuç olarak da davanın yenilenmemesi halinde, boşanma davasının açılmamış sayılması sonucu bu düzenlemenin uygulama alanını oldukça daraltmaktadır. Bu da, kanun koyucunun bu düzenlemeyi yaparken sahip olduğu temel düşünceyle bağdaşmamaktadır.

Ayrıca, dava hakkının sadece ölen davacı eșin mirasçılarına tanımmış olması da, adalet duygusunu zedeler niteliktedir. Kanımızca, olması gereken hukuk açısından, ölen davalı tarafın mirasçılarına da bu tür bir hakkın tanınması menfaat içtihatçılığı bakımından daha isabetli olacaktır. 


\section{BİBLIYYOGRAFYA.}

AKGÜN, ZERRIN : Boşanma Hukuku, İstanbul 1949.

AKINTÜRK, TURGUT: Boşanmanın Hukuki Sonuçları, Ankara Hukuk

Fakültesi Ellinci Yıl Armağanı. (Akıntürk, Boşanma).

: Aile Hukuku, Yenilenmiş 9. Bası, İstanbul 2004.

ALTAŞ, HÜSEYIN : Yabancı ve Türk Mahkeme Kararlarının Mirasç1llğa Etkisi, (Prof. Dr. Turgut Kalpsüz’e Armağan, Ankara 2003).

BAŞAKLAR, EMIN : Nafaka Davaları, Ankara 1974.

BERKİ, ŞAKİR : Boşanma ve Ayrılık, AHFD., 1975, S.1-4, sh.135 vd.

BOZOVALI, HALİL : Türk Medeni Hukukunda Bakım Nafakaları, 1990.

BÜHLER, WALTER/SPÜHLER, KARL : Bernar Kommentar, Kommentar zum Schweizerischen Privatrecht, Band II, Familienrecht, 1. Abteilung, Das Eherecht, Bern 1979.

CYRIL, HEGNAUER/

PETER, BEREITSCHMIT : Grundriss des Eherechti, Vierte überarbeitete Auflage, Bern 2000.

DOĞANAY, İSMAIIL : Nazari ve Tatbiki Nafaka Davaları, Ankara 1961. : Muhtelif Nafaka Davaları, AD., 1953, sh. 3. vd.

ELBİR HALİD. K. : : Boşanma Halinde Maddi ve Manevi Tazminat ve Nafaka Haklarının Toplu Bir Tetkiki, İBD.1948, S. 1, sh.3 vd.

EREN, FÍKRET : Borçlar Hukuku Genel Hükümler, Tıpkı 7. Bas1 İstanbul 2001.

EGGER, AUGUST : Zürcher Kommentari Familienrecht, 1. Abteilung, Das Eherecht (Art. 90-251), 2. Auflage, Zürüich 1936 (Çeviren, Çağa, Tahir, İstanbul 1943).

ESENER, TURHAN : Boşanmadan Mütevellid Maddi Manevi Zararın Ne Zamana Kadar Talep Edilebilir, AHFD., 1951, S. 3-4, sh. 610 vd.

FEYZIOĞLU, NEJMETTIN : Aile Hukuku Dersleri, İstanbul 1971.

GENÇCAN, ÖMER UGUR : 4721 Türk Medeni Kanunu, Bilimsel Açıklama İçtihatlar-İlgili Mevzuat, Madde 1-351, Ankara 2004. 
GÜRSEL, NURETTIN : Nafaka Borcu ve Müessesi, AD., 1948, S. 11 , sh. $1215 \mathrm{vd}$.

GÜRSOY, KEMAL TAHIIR : Destekten Yoksun Kalma Tazminat1, AHFD., 1972, S. 1-2, sh. 143 vd.

: Manevi Zarar ve Tazmini, AHFD., 1973, S. 1-4, sh. 7

vd.

HAKBÍLEN, ADLAN : Yoksulluk Nafakas1, ABD. 1952, sh. 344 vd.

HATEMI, HÜSEYIN/SEROZAN/RONA: Aile Hukuku, İstanbul 1993.

INAL, NIHAT : Yoksulluk Nafakas1 ve Tazminat1, AD., 1970, S. 5, sh. 372 vd.

: Örnek Kararlarla Açıklamalı Boşanma, Nafaka, Eşya,Nişanlanma Davaları, Ankara 1992.

KEMMLER, JUTTA HAHN : Das neue nacheheliche Unterhaltrecht und seine Auswirkungen auf das Sozialrecht, Bochum 1979.

KILIÇOĞLU, AHMET: Medeni Kanun'umuzun Aile-Miras-Eşya Hukukuna Getirdiği Yenilikler Ankara 2003.

: Borçlar Hukuku Genel Hükümler, 3. Bası, Ankara 2003.

KÖPRÜLÜ/KANETİ : Aile Hukuku, 2. Bas1, İstanbul 1989.

KURU, BAKİ/ARSLAN, RAMAZAN/EJDER, YILMAZ: Medeni Usul Hukuku, Ders Kitabı, Genişletilmiş 15. Bası, Ankara 2004.

LEIPOLD, DIETER : Münchener Kommentar Bürgerliches Gesetzbuch Erbrecht, 4. Auflage, München 2004.

OFTINGER/STARK : Schweizerisches Haftplichtrecht, Allgemener Teil, Bd. 1, Zürich 1995.

OĞUZMAN, KEMAL/ÖZ, TURGUT: Borçlar Hukuku Genel Hükümler, Gözden Geçirilmiş ve Genişletilmiş İkinci Bası, İstanbul 1998.

: Aile Hukuku, İkinci. Bas1, İstanbul 1998.

ÖZDEMIR, NEVZAT : Türk-İsviçre Hukukunda Anlaşmalı Boşanma İstanbul 2003.

ÖZTAN, BílGE : Aile Hukuku 5. Bası, Ankara 2004.

ÖZÜĞUR, ALİ İHSAN: Nafaka Hukuku, Ankara 2002.

: Evlilik Birliğini Sona Erdiren Nedenler, Boşanma, Ayrılık ve Evlenmenin İptali Davaları, Aile Mahkemelerinin Kuruluş, Görev ve Yargilama Usulleri, Ankara 2004. 
RUHI, AHMET CEMAL: Türk Hukukunda Nafaka ve Nafaka Alacaklarının Yabancı Ülkelerde Tahsili, Ankara 2003.

SAYMEN FERITT/ELBİR, HALİD K.: Türk Medeni Hukuku, Cilt 3, Aile Hukuku 2., Bası.İstanbul 1960,

SCHWARZ, ANDREAS: Aile Hukuku, (Çeviren, Davran, Bülent) İstanbul

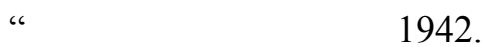

SCHWENZER, INGEBORG : Schweizerisches Obligationenrecht Allgemeiner Teil, Zweite, überarbeite Auflage, Bern 2000.

TULUMLU, MEHMET AKİF: Evliliğin Butlanı, Boşanma, Ayrılık Sebepleri ve Boşanmanın Hukuki Sonuçları Ankara 2002.

ÜYEGÍL, FİKRET : Nafaka Davaları ve Uygulama, AD., 1953, S. 3., sh. $204 \mathrm{vd}$.

YÜCE, TURHAN : Evlilik Hukukunda Nafaka, AD. 1951, S. 12., sh. $1822 \mathrm{vd}$.

ZEVKLILLR, AYDIN/ACABEY, BEŞİR/GÖKYAYLA/EMRE: Medeni Hukuk, Giriş, Başlangıç Hükümleri, Kişiler Hukuku, Aile Hukuku, 6. Bası, Ankara 2000. 